\title{
Situation analysis of the integration of family planning services in postpartum, postabortion and prevention of mother to child transmission programs in the Dominican Republic
}

\author{
Gisela Quiterio \\ Maritza Molina \\ Marija Miric \\ Ricardo Vernon \\ Population Council \\ M. Estela Rivero-Fuentes \\ Population Council
}

Follow this and additional works at: https://knowledgecommons.popcouncil.org/departments_sbsr-rh

Part of the Demography, Population, and Ecology Commons, Health Services Research Commons, International Public Health Commons, and the Maternal and Child Health Commons

How does access to this work benefit you? Let us know!

\section{Recommended Citation}

Quiterio, Gisela, Maritza Molina, Marija Miric, Ricardo Vernon, and M. Estela Rivero-Fuentes. 2008. "Situation analysis of the integration of family planning services in postpartum, postabortion and prevention of mother to child transmission programs in the Dominican Republic," FRONTIERS Final Report. Washington, DC: Population Council. 


\title{
Situation Analysis of the Integration of Family Planning Services in Postpartum, Postabortion and Prevention of Mother to Child Transmission Programs in the Dominican Republic
}

\author{
Centro de Estudios Sociales y Demográficos, A.C. (CESDEM) \\ Gisela Quiterio \\ Maritza Molina \\ Synergy Consulting \\ Marija Miric \\ Frontiers in Reproductive Health, Population Council \\ Ricardo Vernon \\ M. Estela Rivero-Fuentes
}

\section{March 2008}

This study is made possible by the generous support of the American people through the United

States Agency for International Development (USAID) under the terms of Cooperative Agreement No. HRN-A-00-98-00012-00 and Subagreement Number A105.57A. The contents are the responsibility of the FRONTIERS Program and do not necessarily reflect the views of USAID or the United States Government 


\section{SUMMARY}

A diagnostic study of the provision and use of contraception in postpartum, postabortion, and prevention of mother-to-child transmission (PMTCT) programs in the Dominican Republic was conducted with funding from USAID's Latin American and the Caribbean Bureau. The objectives of the study were to assess the contraceptive knowledge, attitudes, and behaviors of providers and clients, the degree to which information, counseling, and delivery are implemented in postpartum, postabortion, and PMTCT services, the quality of these services, and the readiness of postpartum, postabortion and PMTCT services to offer contraceptive services.

Researchers visited and carried out service inventories at 59 hospitals and health centers of the Ministry of Health (MOH), the Dominican Social Security Institute, and Profamilia (the IPPFaffiliate). Interviews were held with 522 health providers (303 in Ob-Gyn wards and 219 in outpatient services), 2,965 women in antenatal care, 879 following their delivery, 162 in postabortion care, 1,421 in the six-month postpartum period, and 156 at HIV integral care units. In five facilities non-intrusive ethnographic observation were undertaken of the context where services were provided and structured observation of client-provider interactions. In-depth interviews were held with 21 providers and 20 users and three focus group discussions with women in the first six months postpartum.

Family planning services are linked to antenatal, delivery and postpartum care in most of the health units visited and, to a lesser degree, to the integral care provided for persons living with HIV. The results have been shared with the $\mathrm{MOH}$ directors of maternal and child health services (DIGEMIA), and with the directors of planning and of the program to prevent mother-to-child transmission of HIV in the HIV/STI department (DIGECITSS); and also with the USAID mission, CONECTA (the Reproductive Health Division of the Dominican Institute of Social Security) and the UNFPA representative. Key findings include the following:

- Health centers and outpatient services in hospitals are well prepared for offering family planning services in the perinatal period. Most of the providers have received training, and family planning counseling is well established in antenatal care.

- Ob-Gyn wards, by contrast, are not sufficiently ready for provision of family planning services to postpartum and postabortion women. Even when 97 percent of the women interviewed during delivery said that they were interested in using a method postpartum, only 12 percent received one before hospital discharge. A further 63 percent said that they would have liked to receive a method before leaving the hospital.

- Access to family planning services during hospital stay are particularly limited for postabortion care clients. Only 12 percent of the women interviewed received family planning counseling, and 9 percent received a contraceptive method before hospital discharge, even when 87 percent would have liked to receive a method before leaving the hospital.

The main obstacles for service delivery provision in hospitals were the following:

- In most establishments, family planning services are offered in the outpatient area and for a limited period of time (usually Monday through Friday during the morning shift), whereas most postpartum and postabortion women are discharged after noon.

- One-quarter of facilities were out of stock of one or more of the contraceptives. 
- Inadequate connection between counseling during antenatal care and delivery of methods during the hospital stay for delivery or postabortion care.

- Lack of referral mechanisms to provide family planning services after hospital discharge to those women interested in obtaining a method.

Other important findings were the following:

- Half of women interviewed during the six-month postpartum period were using a contraceptive method. Women who received family planning counseling during their hospital stay for delivery and in their post-delivery contacts with health providers were more likely to have started contraceptive use than women who did not receive such information. Family planning counseling during antenatal care, however, did not increase the probability of postpartum contraceptive use.

- At least 78 percent of pregnant women had had an HIV test during their antenatal visits and 58 percent received HIV counseling. Also, 83 percent of the hospitals visited conducted at least some PMTCT activities for women in delivery care, including counseling, infant feeding with formula, $\mathrm{C}$-sections and antiretroviral treatment for mothers and their children.

- PMTCT services need to routinely inform women who are having a blood sample taken what tests will be conducted (5\% of the women interviewed in antenatal care who had had a blood sample taken did not know which tests had been conducted.)

- Family planning staff at the Integral Care Units (ICUs) for HIV-positive persons are well trained for providing family planning services to persons living with HIV. They are aware of the potential effect of antiretrovirals on hormonal contraception and that the lactational amenorrhea method is not recommended to women living with HIV if cheap and safe milk substitutes are widely available.

- Contraceptive use among women living with HIV is high (62\%), although there is also a significant discontinuation. In our sample, 30 percent of past users had stopped using a contraceptive, mainly because they do not have a stable partner or because they are not having sexual relations.

Based on this project's findings, key recommendations to improve postpartum and postabortion family planning services include:

- Use the opportunity offered by the dissemination of the 2007 National Family Planning Service Delivery Guidelines for presenting key results of this study and design activities to improve postpartum and postabortion services.

- Design a brochure for pregnant and postpartum women that clearly presents the advantages of spacing the next pregnancy, contraceptive options available for women in the postpartum period, and what a woman needs to do to obtain the services.

- Design an information system to help identify women who decide during antenatal care that they want to start using an IUD or undergo sterilization before discharge.

- Establish the following as routine services in maternities and Ob-Gyn wards: family planning information for all women; offer methods to all women; family planning counseling for all 
women interested in getting a method; and delivery of the chosen method to all women who want one.

- Inform all postpartum women interested in using a hormonal method of its contraindications. If methods are distributed before hospital discharge, give clear, written indications on when to start their use. If methods are not distributed in the hospital, give a written referral stating when and where to obtain them.

- Design brief brochures explaining everything that women in the postabortion and postpartum period need to know regarding emergency symptoms, resumption of fertility and sexual activity, contraception, and follow-up care.

- Providers at maternities and Ob-Gyn wards should receive a brief refresher about the new essential contraceptive practice guidelines, including contraceptive contraindications for postpartum and breastfeeding women, the resumption of fertility after childbirth and an abortion, and follow-up care.

- Review the counseling curricula for PAC clients, as providers need to be more aware of women's emotional and physical health needs.

- In health centers and outpatient services, providers should systematically screen for family planning needs and services; the Population Council's Systematic Screening technique can be adapted for these purposes.

- Study the feasibility of establishing joint care for mothers and children during the first six months after birth.

Key recommendations for improving PMTCT services include:

- Inform all pregnant women who have a blood sample taken which tests will be conducted.

- Design and establish a mechanism to allow providers to identify women who have already had voluntary counseling and testing during antenatal care and the result of the test, while maintaining women's right to confidentiality.

- Increase the linkages between family planning and services at Integral Care Units, either by arranging frequent visits by family planning providers to the ICU or by training the ICU providers to screen for family planning needs and provide contraceptive technology or refer to contraceptive service delivery sites.

- Provide refresher training to family planning providers that give services to women living with HIV/AIDS (WLHA) on the interactions between contraception and antiretrovirals, and include general information about contraception and HIV/AIDS, including women's sexual and reproductive rights, such as the right to reproduce and the right to choose the method they desire without pressure from the provider.

- Use the waiting rooms at the ICUs to show family planning videos and have brochures on the topic available. 


\section{CONTENTS}

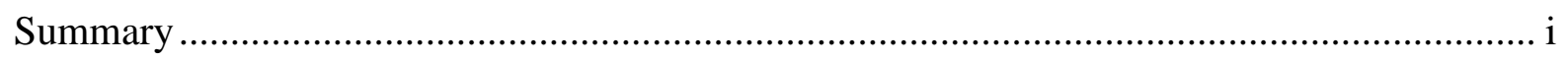

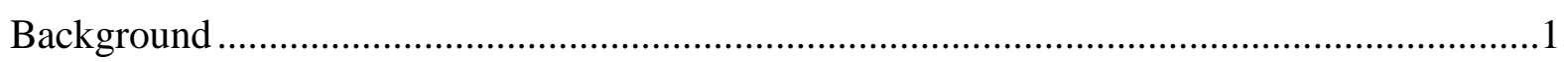

Socio-demographic characteristics and coverage of services ....................................................1

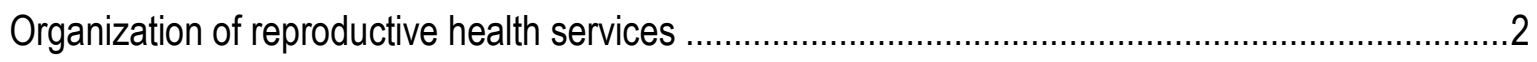

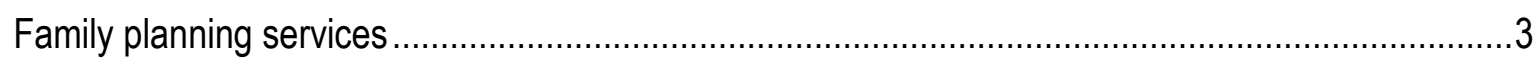

Prevention of Mother-to-Child Transmission of HIV ................................................................. 4

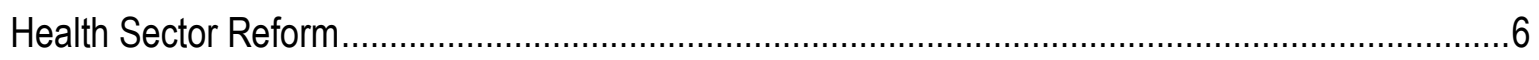

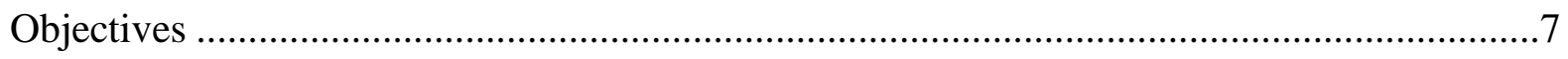

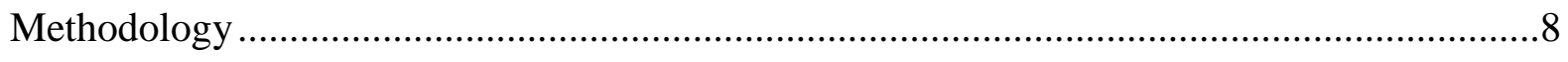

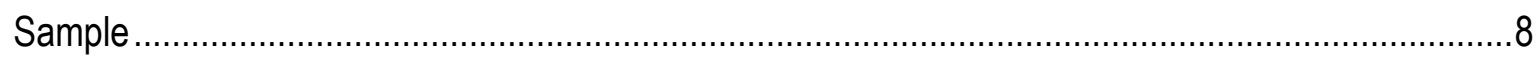

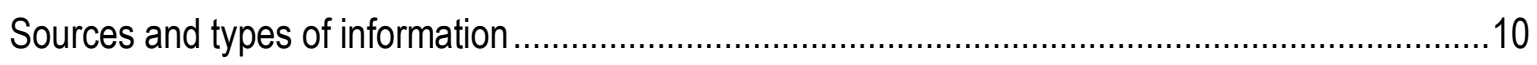

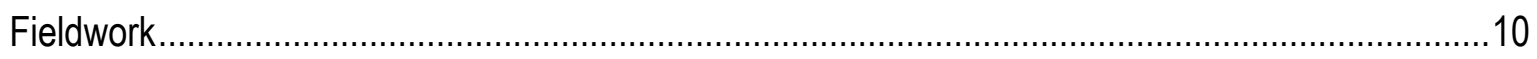

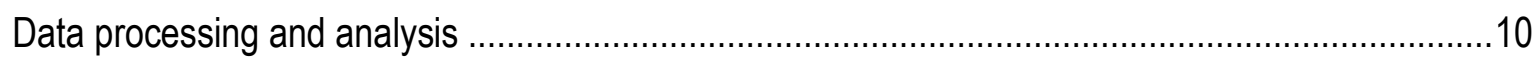

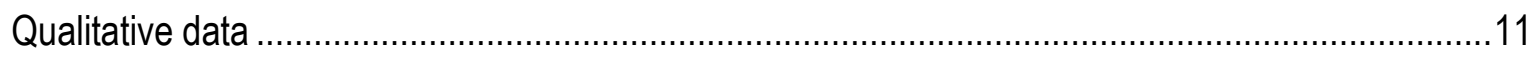

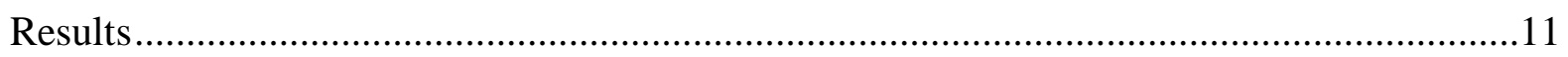

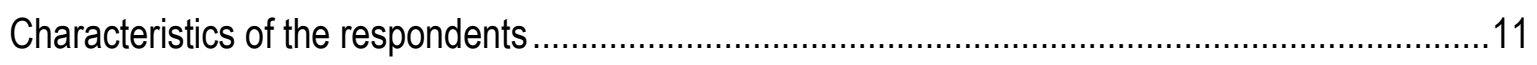

Antenatal, Delivery and Postpartum Care ……………………….......................................13

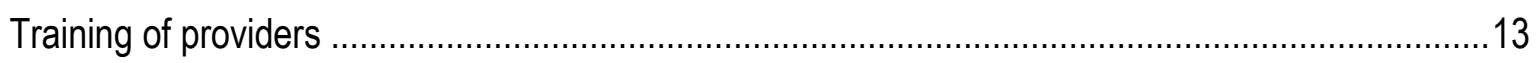

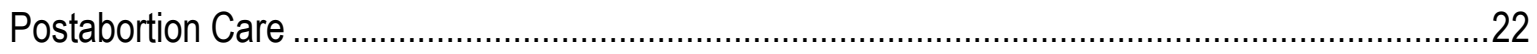

Prevention of Mother-to-Child Transmission of HIV and syphilis ................................................26

Contraceptive services for HIV+ women attending Integral Care Units ..........................................28

Recommendations for improving the quality of services ...................................................29

Key recommendations for improving PMTCT services include: ........................................... 31

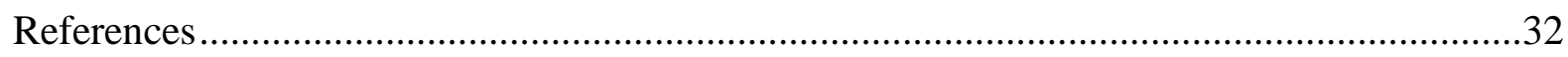




\section{BACKGROUND}

\section{Socio-demographic characteristics and coverage of services}

The Dominican Republic (DR) is located east of Haiti, in the eastern two-thirds of the island of Hispaniola in the Caribbean, between the Caribbean Sea and the North Atlantic Ocean.

According to the 2002 Census, the DR has a population of 8,331,000 inhabitants, of which half is concentrated in the southeastern region of the country (Oficina Nacional de Estadística 2002.) In recent decades, the total fertility rate (TFR) has declined at a very rapid pace, from 6.8 children per woman in the period between 1964 and 1966 to 3.0 children in the period between 2000 and 2002. The contraceptive prevalence rate among 15 to 49 -year-old women in union is estimated at 70 percent and the use of modern methods at 66 percent; female sterilization accounts for twothirds of users. The median age at acceptance of sterilization is 28 years of age, and 22 percent of all women sterilized in the period between 2000 and 2002 went through this procedure before the age of 25 . The pill is used by 13.5 percent, the IUD by 2.2 percent, the injectable contraceptives by 1.9 percent, the condom by 1.3 percent, and all other modern methods are each used by less than 1 percent. Despite the high contraceptive prevalence rate, in 2002 the unmet need for family planning was 11 percent, and 29 percent among adolescents (their prevalence of modern methods is $37.6 \%$ ) (OPS-Macro 2002).

The public sector is the source of contraceptive methods for 43 percent of contraceptive users. While the public and the private sector supply almost even proportions of sterilization, IUD and injectable users, nearly 80 percent of pill and condom users receive their method from the private sector (mostly pharmacies). A similar proportion of implant users receive theirs from the public sector (OPS-Macro, 2002). A recent market-segmentation study showed important differences in the source of contraceptive methods by family wealth, with poorer women being more likely than richer women to receive their contraceptive methods from the public sector (around $57 \%$ of the women in the poorest quintile vs. $27 \%$ of the women in the richest quintile). Still, at least 35 percent of the women in the poorest quintile go to the private sector for contraception (Borda et al. 2004). The same study found that more than 20 percent of women younger than age 29 were not using a contraceptive method, but would like to do so in the near future. The contraceptive preference of these women did not depend on their wealth. More than half (56\%) preferred oral contraception (39\%) and injectables (17\%), and only 13 percent would like to be sterilized. Given the public sector's focus on sterilization and its small share as a source of oral contraceptives, one hypothesis for the large unmet need for family planning among younger women and the relatively young mean age at sterilization is that family planning services in the public sector are insufficient and ill-suited for women who seek to space their births.

The infant and under-five mortality rates declined sharply between 1986 and 2002. The infant mortality rate decreased from 67 to 36 deaths per 1000 children under one year of age, while the under-five mortality rate decreased from 88 to 38 deaths per 1000 children (OPS-Macro 1982 and 2002). Maternal mortality was estimated to be about 150 per 100,000 births in 2005 and 178 per 100,000 in the 2002 DHS (WHO 2005). In spite of advances, maternal and child health indicators in the Dominican Republic are still very poor by international and even Latin American standards. 
These health indicators are puzzling when, over the last decade, there has been nearly universal use of antenatal health care (98\%), qualified delivery care (97\%) and institutional delivery care (96\%, with 76\% of all births attended by the public sector) (OPS-Macro 1996 and 2002). It can be hypothesized that these indicators may be due to poor quality of care. Indeed, an assessment conducted in 2002 in 17 hospitals in three regions presents an appalling picture of obstetric care at most sites visited. To a large degree, poor quality of care seems to be the result of inadequate human resource management and the absence of mechanisms within the health system to make service providers accountable for the services they render. Higher level institutions are inadequately staffed, their staff insufficiently trained, and hospitals badly managed. Service delivery guidelines are not complied with and there are no mechanisms to remedy nonadherence. Specialist and medical staff are often absent and the few paramedical providers available for obstetric care lack the training to respond appropriately to emergencies. The counseling and information, education, and outreach (IEC) in family planning service delivery points are of low quality or nonexistent and method stockouts are common (Miller et al. 2002). Two more recent diagnostic studies failed to observe significantly improved conditions (SESPAS and CONECTA-FHI 2003; Bautista et al. 2004). In addition to these problems, an assessment conducted by UNICEF in 2004 detected deficiencies in the family planning and obstetric services aimed at adolescent women. Most of the activities (90\%) of the adolescent integral health program are for antenatal and postnatal care; the program does not have any activities to prevent first or subsequent pregnancies and it does not have a referral system for family planning services (Bautista et al. 2004).

\section{Organization of reproductive health services}

The largest health service providers in the DR include the Ministry of Health $(\mathrm{MOH})$, the private sector and the Dominican Social Security Institute (IDSS). The Ministry of Health covers about 80 percent of the population; the private sector, which includes private clinics and private insurance companies, covers about 12 percent; and the Social Security covers the remaining eight percent (Morales, 2005).

The country is divided into nine health regions (including the national district of Santo Domingo) and 31 provinces; provinces are then divided into municipalities. The organization of $\mathrm{MOH}$ health services closely follows the political and administrative division. There are six national hospitals in the national district ("Region 0"), of which three provide obstetric services (each takes care of more than 10,000 deliveries per year); there are eight regional hospitals, each with at least four basic specialties (the Santiago hospital, although nominally a regional hospital, fulfills the function of a national hospital); in addition there are 22 provincial hospitals (each covering 2,000 to 3,000 deliveries per year) which, together with the eight regional hospitals, cover nearly all the provinces; and there are 107 municipal hospitals, most of which provide less than 300 deliveries and $\mathrm{C}$-sections per year. In addition, the $\mathrm{MOH}$ provides outpatient services in all these hospitals and in 615 rural clinics, 90 medical dispensaries, 30 sanitary centers and 159 peripheral medical offices.

The IDSS has 19 hospitals, including one national hospital, three regional hospitals, and 18 provincial hospitals, 21 polyclinics and 170 medical offices. The 19 hospitals and 21 polyclinics offer antenatal care services; delivery, C-sections, voluntary counseling and testing (VCT), and postabortion care are only offered in the 19 hospitals (Rivera 2005). 


\section{Family planning services}

The MOH offers family planning services in all its service delivery units, but methods such as IUDs, implants and injectables are offered only at hospitals. The perception is that services have deteriorated since the phase-out of donor funding for family planning in 2006. For these reason, Consejo Nacional de Población y Familia (CONAPOFA) and all other stakeholders are focusing on establishing contraceptive security systems, seeking to ensure that the MOH budget funds the purchase of contraceptives and makes the purchases through a UNFPA-sponsored consolidation system that allows savings of up to 95 percent for contraceptive commodities. A recent study showed that 85 percent of the sites visited did not have injectables, 74 percent did not have combined pills, 45 percent did not have IUDs, and 50 percent did not have condoms (CONAPOFA 2005). CONAPOFA is also providing training in contraceptive methodology, counseling and record-keeping with technical and financial assistance of the USAID/CONECTA project (Blanco 2005).

The IDSS started a reproductive health program in 1997, and until 2002 it received donations of condoms, combined pills and IUDs, and purchased pills and Depo-Provera from Schering, but since 2002 it has not made any purchases (CONAPOFA 2005). With the exception of the Hospital de la Mujer, which receives donations from USAID/CONECTA, and other hospitals which receive sporadic donations from other donors, most hospitals and clinics in the IDSS do not currently have contraceptive supplies. Despite the lack of contraceptive supplies, the 40 outpatient service centers in the IDSS offer family planning counseling in their postpartum services (Sánchez 2005).

In addition to the MOH and the IDSS, nongovernmental organizations, the main NGOs providing these services include ADOPLAFAM (Asociación Dominicana de Planificación Familiar [Dominican Association of Family Planning]), MUDE (Mujeres en Desarrollo [Women in Development]) and PROFAMILIA (Asociación Pro-Bienestar de la Familia Dominicana [Association for the Well-Being of the Dominican Family]). Among the NGOs providing reproductive health $(\mathrm{RH})$ services, ADOPLAFAM has 1,500 community volunteers and one outpatient diagnostic center in Santo Domingo, all of which provide family planning services and antenatal care. MUDE reaches 50,000 rural women in 110 communities through more than 300 volunteers and 110 contraceptive sales points. It also promotes reproductive health services and refers clients to MOH clinical services. PROFAMILIA, the IPPF affiliate, is the largest of the three organizations with strong social marketing and community-based MAC distribution programs, as well as a network of six clinics, of which only one (in the city of3 Santiago) provides obstetric services. As in the case of ADOPLAFAM, PROFAMILIA also provides antenatal care.

There are no statistics available on the proportion of women who receive a contraceptive method before discharge from a hospital after a delivery, during postabortion care, or during postnatal care visits in outpatient clinics. The National Family Planning Service Delivery Guidelines (SESPAS 1999) do not include a special section for postpartum or postabortion contraception; they always discuss it in the context of the eligibility criteria for the different methods. The perception among reproductive health professionals is that although the Dominican Republic served as a training site for many Latin American professionals in postpartum and postabortion 
services during the 1980s and 1990s, contraception is rarely offered or provided in the MOH or IDSS system, except for female sterilization. The strategic assessment conducted in 2001 (Miller et al. 2002) observed that in the 17 hospitals visited "postpartum family planning did not appear to be a major goal of postpartum care" and that "the majority of women who did receive a family planning method postpartum were there for tubal ligation. Reversible methods were not given on discharge." The situation for postabortion contraception seemed to be the same. Regarding the PAC, only one hospital has standardized the use of manual vacuum aspiration (MVA). A diagnostic study of PAC services for adolescents conducted in 2002 in two hospitals in Santo Domingo did not mention contraception but recommends that linkages to family planning services be established, so presumably this service was not available (Girvin 2004). A more recent diagnostic study of PAC services where service providers were interviewed found that 78 percent had no PAC training and 26 percent did not ask women about their future reproductive plans. However, 54 percent of teenage PAC patients and 61 percent of PAC patients older than age 20 left PAC services with a contraceptive method (Youthnet 2004).

\section{Prevention of Mother-to-Child Transmission of HIV}

By February 2005, 15,979 HIV positive cases had been notified in the Dominican Republic, of which 7,496 were AIDS cases. However, estimates suggest that the total number of infections in the country is nearly 10 times the number of cases reported $(141,630)$ and that $2.1 \%$ of adults are infected with HIV (Gómez 2005). Of notified cases, heterosexual relations continue to be the most frequent mode of infection, with 76 percent of the cases, followed by homosexual relations (7\%), use of intravenous drugs $(6 \%)$, perinatal transmission $(2 \%)$ and blood transfusions (the importance of which declined from 5.5 percent between 1993-1997 to 1.2 percent in the following five years). Nearly 80 percent of AIDS cases have occurred in people aged 15 to 44 years, and 19 percent among young people aged 15 to 24 years. Although nearly two-thirds of the cases overall have occurred in men, among those between ages 15 and 24, 49 percent of the infections occur in men and 51 percent in women. Different studies have found that the prevalence in high-risk groups may be as high as 12.4 percent for commercial sex workers, 6.7 percent among STD patients, and 11 percent among men having sex with men (SESPAS 2005).

In 2002, the National Program for the Reduction of HIV/AIDS Vertical Transmission was created with the purpose of reducing mother-to-child transmission by implementing promotion, prevention, and control strategies and actions. Key strategic program areas include pre- and posttest counseling, provision of Nevirapine and other antiretrovirals to mother and child, $\mathrm{C}$-sections for HIV positive women on the $38^{\text {th }}$ week, negotiation of use of breast milk substitutes, and follow-up of mothers and children in the program (SESPAS 2005). The program is implemented by the $\mathrm{MOH}$ and other governmental and non-governmental organizations. Within the $\mathrm{MOH}$, the General Direction for the Control of Sexually Transmitted Diseases and AIDS (DIGECITSS) coordinates the program. The program is funded by the World Bank, the Millennium Development Goal Funds, and other private international donors. 
Table 1 summarizes the PMTCT activities implemented at each health care level and the number of units that are supposed to be conducting the activities and are estimated to be actually doing so in 2005 (Suazo 2005).

Table 1: Number and Type of Health Facility Implementing PMTCT Program Activities

\begin{tabular}{||c|l||}
\hline \multicolumn{1}{|c|}{ Activity } & \multicolumn{1}{|c||}{ Number and Type of Health Care Facility } \\
\hline \multirow{2}{*}{$\begin{array}{c}\text { Voluntary counseling and testing for pregnant } \\
\text { women }\end{array}$} & $\begin{array}{l}\text { All National, Regional, Provincial and } \\
\text { Municipal Hospitals (122 hospitals) in the } \\
\text { MOH, IDSS, several NGOs and the Armed } \\
\text { Forces Military Hospitals. }\end{array}$ \\
\hline Antenatal and delivery care for HIV + women & $\begin{array}{l}\text { All National, Regional Provincial and } \\
\text { Municipal Hospitals (122 hospitals) in the } \\
\text { MOH (probably 90 are currently active), IDSS, } \\
\text { Armed Forces Military Hospitals and other } \\
\text { private institutions }\end{array}$ \\
\hline \multirow{2}{*}{ Follow-up of HIV + adults, including ART } & $\begin{array}{l}\text { Sixteen Integral Care Units (ICU). But only an } \\
\text { estimated 13 are currently functioning, } \\
\text { including NGOs }\end{array}$ \\
\hline Follow-up of HIV + infant & $\begin{array}{l}\text { Pediatric Integral Care Units (PICU). Six } \\
\text { planned, but currently only two working }\end{array}$ \\
\hline
\end{tabular}

At the time of this study, 1,402 children had been born under this program. In 2004, 12,321 women made a first antenatal care visit and 45.4 percent of these had a voluntary test. Estimated HIV prevalence in this population was 1.2 percent. Sixty percent of the women in the PMTCT program had a C-section in 2004. The two Integral Care Units (ICUs) working at the time provided support services to 301 children. However, the provinces in which HIV prevalence among pregnant women was over six percent were precisely those provinces where lower proportions of women were tested (less that 25 percent in four out of the six provinces with the highest HIV prevalence) (Betts 2005). Other indicators also show improvements over time in nearly all aspects of the PMTCT Program.

Nevertheless, a 2005 evaluation found shortcomings such as little use of the data at the provincial and hospital levels despite the reasonable functioning of the information system, differential access to services, lack of participation of provincial and municipal managers in program activities, lack of integration with other health programs, and lack of plans to financially sustain the program once the World Bank and Millennium Development Goal (MDG) funds are exhausted (Betts 2005). Another 2004 review of PMTCT programs in 11 countries (Rutenberg and Baek 2004) found that managers in two DR hospitals said contraception was part of their PMTCT program, encouraging HIV positive women to undergo sterilization during their elective caesarean or 10 days after delivery, and condoms are actively offered to HIV + clients. In one hospital it was reported that 99 percent of the HIV positive women accepted sterilization. Nevertheless, the National STI/HIV/AIDS Counseling Guidelines (SESPAS 2003) devote only one line to contraception, not taking into account discussions regarding the use of condoms to reduce the risk of HIV infection. Likewise, none of the program managers interviewed to develop the proposal for this study mentioned contraception as a program component, other than the use of condoms to avoid transmission. 


\section{Health Sector Reform}

A health sector reform process was started in the Dominican Republic in 2001. The reform implies a change in the organization and funding of health services. The population is expected to enroll in a Health Risk Administration company (HRA) which will subcontract the delivery of health services to independent clinics and hospitals. Enrollment in an HRA has an average annual premium of $2,276^{1}$ Dominican pesos (approximately US\$100) per capita and it covers a package of basic health services defined by the National Council of Social Security (Morales 2005). The choice of HRA and how much an individual will have to pay for enrollment depends on his or her work and socioeconomic situation. There are three different health care plans:

1) A contribution plan, which will cover workers in the formal sector and their immediate family members, including wife, children younger than 18, and parents who are not covered elsewhere. In this regime, the worker will cover one-third of the premium, up to 10 percent of his or her salary, and the employer will cover two-thirds. HRA companies working on a contribution regime include private HRAs and the former National Health Insurance (IDSS), which is starting to work as an HRA.

2) A subsidized contribution plan, which will cover informal and self-employed workers and their immediate family members. These workers represent about 55 percent of the workforce. In this regime, the worker will contribute one part of the premium and the government will cover the rest. The only HRA that will be available in this regime is the National Health Insurance (Seguro Nacional de Salud, or SENASA). SENASA is a public HRA which will derive from the transformation of the current Ministry of Health into a health risk administrator.

3) A subsidized plan, which will cover public-sector employees and the poorest families in the country. In this regime, the government will cover the whole premium. As in the subsidized contributive regime, SENASA will be the only HRA available (Morales 2005 and IDSS 2005).

The exact implications of the health reform process for the access and quality of family planning services, postnatal and postabortion care, and PMTCT services are still unknown. However, several elements in the health reform basic plan and legislation hint that the incentives for providing these services and the mechanisms to monitor their quality will change. For example, the health reform will imply a decentralization of the MOH and the IDSS and greater autonomy at the clinic and hospital levels. Currently, the central offices of the $\mathrm{MOH}$ and the IDSS make all decisions relative to their hospitals and clinics, including a priori budget allocations and the hiring of administrative and non-professional staff. Once the $\mathrm{MOH}$ and the IDSS operate as HRAs (under the names of SENASA and IDSS), hospitals and clinics will not receive an a priori budget but will be paid for the number of actual services they provide. Hospital and clinic administrators will have to decide what services they offer and which family planning methods they buy and have in stock. The population will be able to choose among different clinics and hospitals within the same HRA, bringing a new competition among service providers.

\footnotetext{
${ }^{1}$ There have been some discussions about increasing the average annual premium to $\$ 6,381$ Dominican pesos. (Morales, 2005).
} 
An additional change foreseen in the reform that is likely to affect PMTCT services is that antiretroviral therapies and contraceptive implants are not included in the package of basic health services defined by the National Council of Social Security. The HRS will only provide donated ARVs. Antiretroviral therapies will be the responsibility of the public sector government, but the mechanisms for distributing them across clinics and hospitals has not been clearly established yet. Some HRAs, such as the IDSS (Sánchez 2005), may choose to offer ART in the services they provide, but others may not.

The health reform establishes that enrollment into a HRA should be universal. Nevertheless, there are no clear mechanisms to enforce enrollment, especially in the case of self-employed and informal workers (55\% of the labor force population) and their families. As the un-enrolled population will have to pay for any health services from their own pocket, the health reform may cause a reduction in access to reproductive health services. Whether or not this will occur has yet to be explored.

To date, the basic plans and legislation for the health reform have been laid out, but the implementation process has started only in the southern (region IV) and in eastern parts (region V) of the country. RedSalud, a project supported by USAID, has been assisting the implementation of the reform in region V provinces (El Seibo, La Altagracia, La Romana, San Pedro de Marcorís and Hato Mayor). Among other activities, their assistance has helped to establish the Directorate of Information and Defense of the Enrolled Population (DIDA by its Spanish acronym), making a listing of potential enrollees and helping to identify the poorest families in the region. While reforms in these two regions is still in its early stages, there are currently about 76,000 individuals enrolled and 8,000 individuals to be enrolled in region five in the near future. In addition, enrollees have started to demand the payment of their prescription drugs.

\section{OBJECTIVES}

The general objective of this project was to conduct a situation analysis of the provision and use of contraception in postpartum care, postabortion care, and PMTCT services in the Dominican Republic.

The specific objectives were to assess the:

1. Contraceptive knowledge, attitudes and behaviors of providers and clients of postpartum, postabortion, and PMTCT services.

2. Degree to which information, counseling and method delivery services are implemented in postpartum, postabortion, and PMTCT services, and the quality of these services.

3. Readiness of facilities to provide contraceptive services within postpartum, postabortion, and PMTCT services. 


\section{METHODOLOGY}

The situation analysis consisted of direct observations of the resources available at facilities, interviews with service providers and clients, and an assessment of supporting systems, such as supervision, training, management information systems, and IEC activities. These activities were conducted in primary, secondary, and tertiary care facilities by the Centro de Estudios Sociales y Demográficos (CESDEM), with technical assistance from the Population Council's Frontiers in Reproductive Health. CESDEM is a private, non-profit organization that provides research and evaluation services in health, population, and social development themes and has conducted large studies in the health sector, including most of the studies related to the Health Reform as well as the most recent Demographic and Health Survey in the Dominican Republic.

\section{Sample}

A recent market-segmentation study revealed that contraceptive use and the source of contraceptive methods varied according to poverty level (Borda et al. 2004). To observe hospitals and health units with different socioeconomic and health infrastructure characteristics, provincial and municipal hospitals and primary health units were selected in a multi-stage process. First a sample of provinces was selected, within which hospitals, municipalities, and health units were selected. To obtain the sample of provinces, the 31 provinces were categorized according to three criteria: the proportion of households living below the poverty line, their urbanization level, and the number of doctors per 10,000 inhabitants. The combination of these categories yielded 12 groups of provinces, as described in Table 2 . One province was randomly selected in each group. In addition, all the provinces of sector $\mathrm{V}$ (where the health sector reform had begun) and the National District were included.

Table 2. Distribution of provinces in the Dominican Republic, by poverty, urbanization and health infrastructure level

\begin{tabular}{|c|c|c|c|c|}
\hline & & \multicolumn{3}{|c|}{ Health infrastructure } \\
\hline Poverty level & $\begin{array}{c}\text { Urbanization } \\
\text { level }\end{array}$ & Low & Medium & High \\
\hline Extremely poor & Urban & & & Independencia \\
\hline Extremely poor & Rural & $\begin{array}{c}\text { Azua } \\
\text { Sánchez Ramirez } \\
\text { San Juan } \\
\text { Monte Plata }\end{array}$ & $\begin{array}{c}\text { Maria Trinidad S. } \\
\text { Elías Piña } \\
\text { El Seybo }\end{array}$ & $\begin{array}{c}\text { Santiago Rodrigo } \\
\text { Samaná }\end{array}$ \\
\hline Poor & Urban & Valverde & $\begin{array}{c}\text { Monseñor Nouel } \\
\text { Barahona }\end{array}$ & $\begin{array}{c}\text { Duarte } \\
\text { La Altagracia } \\
\text { Pedernales } \\
\text { Hato Mayor }\end{array}$ \\
\hline Poor & Rural & $\begin{array}{c}\text { Bahoruco } \\
\text { Puerto Plata } \\
\text { Espaillat }\end{array}$ & $\begin{array}{c}\text { La Vega } \\
\text { Dajabón } \\
\text { San Cristóbal }\end{array}$ & $\begin{array}{c}\text { Montecristi } \\
\text { Salcedo } \\
\text { Peravia }\end{array}$ \\
\hline Moderately poor & Urban & La Romana & & $\begin{array}{c}\text { Distrito Nacional } \\
\text { Santiago } \\
\text { San Pedro de M. }\end{array}$ \\
\hline
\end{tabular}


In each of the provinces sampled, the regional hospital (if there was one), the provincial hospital, one municipal hospital, and two health clinics were selected. The selection was not completely random; to increase the policy relevance of the findings, the three national hospitals that provide obstetric care (all in region 0) were included in the sample, as well as the five hospitals where the USAID/CONECTA project had been providing technical assistance to improve obstetric care (Villa Mella, Alcarrizos II, Engombe, and El Almirante in region 0, and Gonzalbo de la Romana in region V), the Profamilia clinics in Santo Domingo and Santiago, the two IDSS hospitals that delivered the largest number of births in 2004 (Hospital de la Mujer in Santo Domingo and the regional hospital in Santiago), and all the Integral Care Units (ICUs) in the country. The final sample included 59 service delivery units, including five national hospitals, six regional hospitals, 10 provincial hospitals, 19 municipal hospitals, and 19 health centers. Of these establishments, 20 were functioning as ICUs.

In the hospitals, all women who had had a delivery or postabortion care were approached right before they were discharged (nurses helped identify these women). In outpatient services, women attending antenatal care, women attending the health center for any reason who had had a delivery in the last six months, and women receiving HIV/AIDS follow-up services were interviewed. At outpatient services of national and regional hospitals, one in four women attending services were interviewed. In each service delivery unit, at least eighty percent of staff providing the above-mentioned services were interviewed. Table 3 presents the total number of interviews conducted in each case.

Table 3. Number of observations, according to type of establishment

\begin{tabular}{|c|c|c|c|c|c|c|}
\hline \multirow{2}{*}{ Type of observation } & \multicolumn{5}{|c|}{ Type of establishment } & \multirow{2}{*}{ Total } \\
\hline & $\begin{array}{l}\text { National } \\
\text { hospitals }\end{array}$ & $\begin{array}{l}\text { Regional } \\
\text { hospitals }\end{array}$ & $\begin{array}{l}\text { Provincial } \\
\text { hospitals }\end{array}$ & $\begin{array}{c}\text { Municipal } \\
\text { hospitals }\end{array}$ & $\begin{array}{l}\text { Health } \\
\text { centers }\end{array}$ & \\
\hline \multicolumn{7}{|c|}{ Observation of services } \\
\hline Maternity and Ob-Gyn wards & 5 & 6 & 10 & 19 & & 40 \\
\hline Outpatient services & & & & & 19 & 19 \\
\hline \multicolumn{7}{|c|}{ Interviews with providers } \\
\hline $\begin{array}{l}\text { Providers in the maternity and } \\
\text { Ob-Gyn wards }\end{array}$ & 79 & 74 & 57 & 90 & 3 & 303 \\
\hline Outpatient services & 46 & 38 & 38 & 41 & 56 & 219 \\
\hline \multicolumn{7}{|c|}{ Interviews with users } \\
\hline Antenatal care & 849 & 686 & 661 & 472 & 297 & 2965 \\
\hline After delivery & 381 & 233 & 196 & 69 & & 879 \\
\hline Postabortion care & 95 & 26 & 31 & 10 & & 162 \\
\hline $\begin{array}{l}\text { In the six-month postpartum } \\
\text { period }\end{array}$ & 359 & 322 & 304 & 248 & 188 & 1421 \\
\hline ICU users & 33 & 56 & 41 & 3 & 23 & 156 \\
\hline
\end{tabular}




\section{Sources and types of information}

Nine data collection instruments were designed and tested: two observation guides to assess service delivery conditions and resources (one for maternity and Ob-Gyn wards and one for outpatient services); two for interviews with health providers (one for providers in the maternity and $\mathrm{Ob}-\mathrm{Gyn}$ wards and one for providers in health centers and outpatient services); and five for users (one for women in antenatal care, one for women who had just delivered, one for women who had just received postabortion care, one for women in the six-month postpartum period and one for ICU users). These instruments were discussed with staff members of USAID, CONECTA, the Maternal-Child General Direction (DIGEMIA) and the General Direction for the Control of Sexually Transmitted Diseases and AIDS (DIGECITSS). Several pretests were conducted to ensure that respondents fully understood the final wording of the instruments and that the duration allowed time to capture reliable information.

The questionnaires for women collected information on their socio-demographic characteristics, reproductive and contraceptive history, characteristics of the services received, and knowledge, attitude and practices regarding pregnancy, delivery, abortion and the following months after these obstetric events, HIV and AIDS, breastfeeding, contraception, as well as their perceptions of the quality and costs of the services they received.

The questionnaires for providers collected information on their socio-demographic characteristics, training and experiences in reproductive health service delivery, including contraception, antenatal care, delivery care, postpartum and postabortion care, HIV care and counseling in these topics.

The observation guides assessed the number and type of service providers, the services provided, type of family planning services offered and the way they were organized, services for adolescents, availability of contraceptive and medical supplies, IEC materials, audiovisual and other equipment, the organization of family planning services, and the existence and use of a management information system.

\section{Fieldwork}

Fieldwork was conducted between June 26 and September 8, 2006 by 22 interviewers, five supervisor-interviewers and one coordinator, after receiving five days of training. During training, the instruments and informed consent procedures were reviewed and role-playing exercises conducted, in which participants alternated the roles of interviewer and respondent. To facilitate data collection, SESPAS and IDSS informed the directors of the service delivery units of the dates when the interviewers would visit. The fieldwork coordinator visited each health unit one week before the visit to explain the objectives of the study and the activities that would be conducted.

\section{Data processing and analysis}

Data processing was conducted in three stages. First, supervisors reviewed the completed questionnaires to reduce non-responses and inconsistencies between questions. In the case of inconsistencies in the responses of clients, the interviewer tried to remember the interview to solve the problem. Inconsistencies in provider responses and in the observation guides were 
resolved in a follow-up visit to the health unit. Second, open-ended questions were coded and closed questions reviewed. Third, data entry and cleaning was undertaking using SSPRO, and data were exported to SPSS and STATA for analysis.

Data analysis consisted of frequencies and cross tabulation. No data weighting was used because part of the sample selection was non-random and responses represent the interviewed population only. Non-responses were excluded from the analysis, assuming that the distribution of these responses would have been the same as of those who answered the questions.

\section{Qualitative data}

Qualitative data were collected in a sub-sample of five hospitals (one national, two regional, one provincial, and one municipal) using the following methods:

- Non-intrusive ethnographic observation of the context where services were provided

- Structured observations of client-provider interactions during antenatal care (5), hospital stay for delivery (4), and postabortion care (3)

- In-depth interviews with 21 providers, including two hospital directors, two providers in ICUs, nine providers in the Ob-Gyn ward (five physicians and four nurses), and four providers in family planning services

- In-depth interviews with 20 users, including interviews with six women in antenatal care (one of them in a ICU), six with women who had just delivered, three with postabortion clients, and five with women in the six-months postpartum period (one of them living with HIV)

- Three focus group discussions with women in the first six months postpartum.

Women who participated in the focus group discussions and in the in-depth interviews were compensated about $\$ 4$ for their time after they had signed the informed consent form, and so was not an inducement for their participation. To maintain confidentiality, the instruments did not record the name of the hospitals or of the respondents. All interviews and focus groups were taped and transcribed for analysis through organization and interpretation by topic.

\section{RESULTS}

\section{Characteristics of the respondents}

A total of 5,583 women were interviewed, including 2, 965 who were attending antenatal care, 879 before discharge from the hospital after a delivery, 162 before discharge from the hospital after postabortion care, 1,421 in the first six months after a delivery or an abortion, and 156 who had received HIV/AIDS services.

Women attending for HIV/AIDS services were older than women attending for other services: only three percent of these women were younger than age 20 and 37 percent were 35 or older, a distribution very similar to that observed in the ENDESA 2002 for women living with HIV/AIDS (CESDEM 2003). In contrast, at least one-quarter of the other respondents were 20 years old or younger and less than 10 percent were 35 years or older. Sixty-six percent of the women who had received postabortion care were between 20 and 34 years old (see Table 4). 
Over 70 percent of all respondents were married or in union, except for women with HIV/AIDS, 54 percent of whom were separated, divorced or widowed, either because they were abandoned after their HIV status became known or because their partners died. HIV+ women were also less educated than the other women: 70 percent had less that primary schooling ( $28 \%$ between one and four years and $43 \%$ between five and eight years), in contrast to the more than 50 percent of other women who had more than eight years of education and about 10 percent who had only between one and four years of schooling.

\section{Table 4. Socio-demographic characteristics of respondents}

\begin{tabular}{|c|c|c|c|c|c|}
\hline \multirow[t]{2}{*}{ Characteristic } & \multicolumn{5}{|c|}{ Type of interview } \\
\hline & $\begin{array}{c}\text { Antenatal } \\
\text { care } \\
(\mathrm{n}=2965)\end{array}$ & $\begin{array}{c}\begin{array}{c}\text { After } \\
\text { delivery } \\
(\mathbf{n}=879)\end{array} \\
\end{array}$ & $\begin{array}{l}\text { Six months } \\
\text { postpartum } \\
(\mathrm{n}=1421)\end{array}$ & $\begin{array}{c}\text { Postabortion } \\
\text { care } \\
(\mathbf{n}=162) \\
\end{array}$ & $\begin{array}{c}\text { ICU } \\
\text { clients } \\
(n=156) \\
\end{array}$ \\
\hline \multicolumn{6}{|c|}{ Age } \\
\hline$<20$ & 38 & 29 & 26 & 27 & 3 \\
\hline $20-34$ & 58 & 67 & 69 & 66 & 60 \\
\hline$>35$ & 4 & 4 & 5 & 7 & 37 \\
\hline \multicolumn{6}{|c|}{ Education } \\
\hline $4^{\text {th }}$ grade or less & 10 & 14 & 9 & 9 & 28 \\
\hline $5^{\text {th }}-8^{\text {th }}$ grade & 36 & 35 & 30 & 37 & 43 \\
\hline Secondary & 44 & 42 & 43 & 50 & 25 \\
\hline College & 10 & 9 & 17 & 4 & 4 \\
\hline \multicolumn{6}{|c|}{ Marital status } \\
\hline Single & 5 & 3 & 5 & 11 & 2 \\
\hline Married /cohabiting & 87 & 87 & 86 & 79 & 44 \\
\hline Divorced/widowed & 8 & 10 & 9 & 11 & 54 \\
\hline \multicolumn{6}{|c|}{ Net parity } \\
\hline $\mathbf{0}$ & 4 & 1 & 0 & 11 & 4 \\
\hline $1-2$ & 75 & 67 & 70 & 62 & 43 \\
\hline 3 or more & 21 & 32 & 30 & 27.4 & 53 \\
\hline
\end{tabular}

Of the 522 providers interviewed, 303 worked on the maternity and Ob-Gyn wards at hospitals and 219 in units providing outpatient services. Of these, 75 percent were female, one quarter were under age 35, 37 percent were between ages 35 and 44, and 9 percent were older than 55 . Nearly one third were nurse auxiliaries and 23 percent were obstetricians. Sixteen percent were general practitioners, 13 percent were nurses and 17 percent were other service providers. The majority (32\%) graduated between five and 15 years ago or between 15 and 24 years ago (31\%). 


\section{Box 1. Clients of Haitian ancestry and poor, less educated women can face discrimination in the provision of health services}

Even though there are no official service delivery guidelines or policies to exclude non-Dominicans from receiving health services in public clinics and hospitals, interviews with providers unveiled several forms of discrimination against Haitians and people of Haitian ancestry. Discrimination occurred throughout the country, not only in border towns, and ranged from denial of health services to being ruder to them than to other patients.

For example, the norm in one of the health establishments in a border town was that, with the exception of medical emergencies, they should not serve Haitians. Even opening clinical histories was forbidden. One provider from this center explained:

"We see less Haitians here than in other hospitals in the country, and so this has a logic. We are less than 30 meters from Haiti, and if we open the doors to Haitians, then we will not see any more Dominicans here. All the beds will be full with Haitians."

The study also found signs of discrimination against less educated women. During the ethnographic observations in outpatient services, researchers witnessed a physician who was using the antenatal care session with a woman who seemed to be very poor to train seven students. They were all in the same office and the physician was talking about the importance of the socioeconomic and educational status of women. He told the students, right in front of the woman, that socioeconomic status can tell them "what to expect from these women", because sometimes they request a lab test and they use the results to "withdraw the pots from the stove" (referring to having an abortion). He later said, "You cannot expect much from these ignorant [people]." All the students laughed while the woman watched them in silence.

\section{Antenatal, Delivery and Postpartum Care}

According to Ross and Winfrey (2001), the greatest unmet need for contraception can be found among women in the first year after having a birth. To decrease the number of short intervals between delivery and the next pregnancy, which are a health risk for mothers and children (Trussell and Pebley 1984, Dewey and Cohen 2007), as well as unplanned pregnancies, unsafe illegal abortions and maternal deaths, WHO (1994) recommends that trained providers give women information on all contraceptive options available, their risks and benefits, and their effectiveness, and to let women who desire to use a method choose one from as many options as possible. The following results describe the degree to which these conditions were found in the service delivery units visited.

\section{Training of providers}

Less than one half of all providers interviewed (44\%) said that they provided counseling on contraception, and of these, about 80 percent said they had received formal training in FP. One of the weakest areas in their training was on contraindications for use of the different methods in the postpartum period.

A smaller proportion of providers (17\% in the Ob-Gyn ward and $43 \%$ in outpatient services) said their job included providing contraceptive methods; all of these had received formal training in family planning. A larger proportion of providers in maternities and hospitals than in health centers have received training in female sterilization and IUD. For all other methods, the proportion of providers who had been trained is greater in health centers. Likewise, a larger 
proportion of providers had received training on combined and progestin-only pills, the IUD, and the condom than on other methods.

Table 5. Proportion of providers that have received FP training, by type of unit, type of FP services provided and type of training received

\begin{tabular}{||l|c|c||}
\hline TYPE OF FP SERVICES PROVIDED AND FP & \multicolumn{2}{c||}{ TYPE OF UNIT } \\
SERVICES TRAINING & $\begin{array}{c}\text { Outpatient } \\
\text { services }\end{array}$ & $\begin{array}{c}\text { Maternities and Ob- } \\
\text { Gyn wards }\end{array}$ \\
\hline & $\mathbf{\%}$ & \% \\
\hline Providers that give counseling services & $\mathbf{( n = 9 2 )}$ & 75.0 \\
\hline FP counseling techniques & 85.9 & 79.3 \\
\hline Advantages of the different methods & 91.3 & 73.5 \\
\hline Mechanisms of action of methods & 87.0 & 71.3 \\
\hline Method use indications & 89.1 & 59.0 \\
\hline Methods contraindicated in the postabortion period & 83.7 & $\mathbf{( n = 5 2 )}$ \\
\hline Providers that provide FP methods & $\mathbf{( n = 9 4 )}$ & 100 \\
\hline Training in FP methods & 94 & 69 \\
\hline Combined oral contraceptives & 84 & 69 \\
\hline Progestin-only pills & 79 & 87 \\
\hline Interval IUD & 77 & 73 \\
\hline Postpartum/Postabortion IUD & 69 & 67 \\
\hline Condoms & 76 & 69 \\
\hline Depo-Provera & 82 & 56 \\
\hline LAM & 68 & 50 \\
\hline Other natural methods & 65 & 65 \\
\hline Female sterilization & 53 & 21 \\
\hline Vasectomy & 29 & 15 \\
\hline Norplant & 10 & \\
\hline \hline
\end{tabular}

The Lactation Amenorrhea Method (LAM) is a key method for postpartum care, given that it is 98 percent effective and promotes the use of exclusive breastfeeding, which is associated with improved nutrition and health outcomes of children (Family Health International 1996). The lactation amenorrhea method is effective when three conditions are present: exclusive or near exclusive breastfeeding, absence of menses, and less than six months after a delivery (Family Health International 2007). Only one third of all providers were able to mention these three conditions. Curiously, the proportion of providers who know the three conditions at hospitals was only 15 percent compared to 54 percent of providers in outpatient services.

The WHO eligibility criteria advise that breastfeeding women should not use combined oral contraceptives and that progestin-only pills, injectable contraceptives and implants should not be used during the first six weeks postpartum to avoid exposing the infant to potential side effects. Breastfeeding women are also advised not to use periodic abstinence methods (FHI 2007b, WHO 2006). Thirty-eight percent of providers who provide counseling services were not able to mention the methods that breastfeeding women should not use (46\% in Ob-Gyn wards and $24 \%$ 
in outpatient services). Among those who could name contraindicated methods, the most frequently mentioned were combined pills (49\%) and injectables (23\%). Combined pills were mentioned by 63 percent of providers in outpatient services and 38 percent in Ob-Gyn wards; injectables by 31 percent and 17 percent respectively.

Only 40 percent of antenatal care providers in outpatient services, and $45 \%$ of postnatal care providers on Ob-Gyn wards, reported giving information on family planning methods that women can use after delivery. In outpatient services, 73 percent of providers gave antenatal counseling and one half included counseling on postpartum FP methods. Only 28 percent provided counseling to postpartum women, but three-quarters of these included contraception in their counseling. The topics covered during counseling sessions are described in Figure 1.

\section{Figure 1: Methods discussed by providers during FP counseling sessions by place of work}

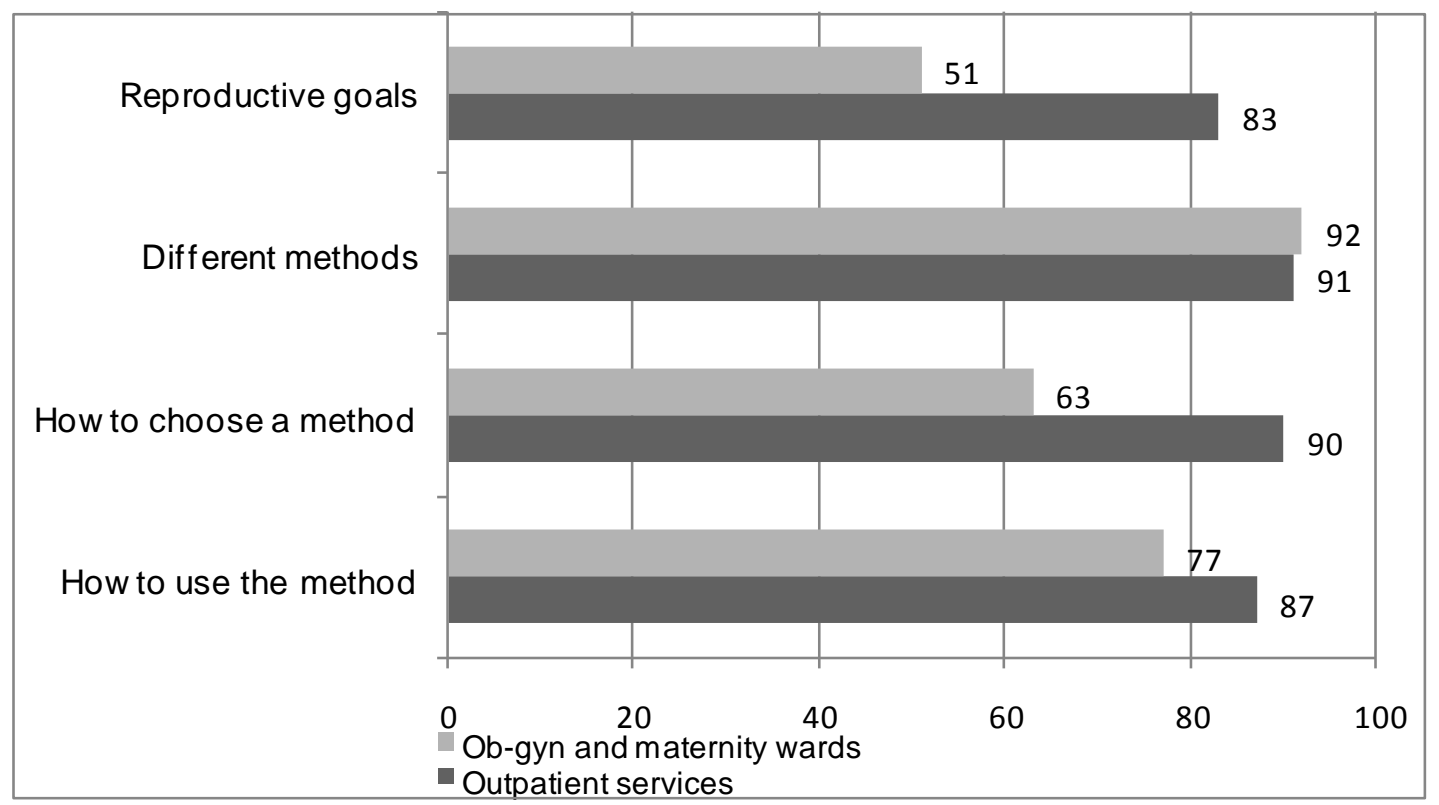

\section{Family planning information received during antenatal and postnatal care}

Only 55\% of women attending antenatal care and $41 \%$ of women in the first six months postpartum reported receiving counseling. Adolescents were the most likely to receive counseling, whereas women older than 34 years of age were the least likely: 62 percent of women under 20 in antenatal care and 53 percent attending postpartum care received counseling, compared to 43 percent and 41 percent, respectively, of women 35 years or older. Likewise, women with moderate levels of education (59\% of those with 5 to 8 years of schooling and $55 \%$ of those with some secondary schooling) were more likely to be counseled than women with low or high levels of education (49\% of those with less than five years and $50 \%$ of those with some university education). 


\section{Box 2. Misinformation and false beliefs still affect contraceptive use}

Even though contraceptive knowledge and use in the Dominican Republic are high, focus group participants often mentioned misconceptions about contraceptives and contraceptive use. One was that there is a male injection; another was that using a contraceptive may produce sterility, especially among nulliparous women:

"I was told that if you use a method when you do not have any children, you can become infertile or something... that it causes you problems later on."

Other women believed that continuous contraceptive use may help them become pregnant. And yet others had erroneous ideas about how to use certain contraceptive methods or about their side effects. One woman, trying to explain the different contraceptive methods she had heard of said:

"I was told that there are pills, condoms, thermometers... [In the method of the thermometer], when you have sex with your husband, when you finish, you put the thermometer in your vagina. You leave it there for three minutes. If it marks $37^{\circ} \mathrm{C}$, then you are OK."

Some women also commented being afraid of the IUD, which "can get lost inside" and "hurt [the] husband, who feels it during sex." Others mentioned the side effects of injectable contraceptives, especially the absence of menses for three months:

"My niece is using an injection and she lasts three months without menstruating. I say that must be harmful. How can someone be three months with that blood inside of them? Because if women menstruate every month, it is because they do not need that blood. That blood can stay in your ovaries and clog you."

Other obstacles for contraceptive use had to do with cultural beliefs and social norms. For example, we found three women who wanted to be sterilized but were waiting to have a boy (one of them had five girls, and another had two girls and two boys but had recently remarried).

\section{Postpartum contraceptive delivery and use}

Ninety-seven percent of the women interviewed before discharge after a delivery said they were interested in using a contraceptive method, but only 12 percent received one during their stay. A further 63 percent would have liked to receive a method during their stay, but did not get it. When asked why they had left the hospital without a method, 61 percent had not been offered one and 17 percent had been advised to wait a little time before starting use. Two percent of women were told that the method they desired was not available. The vast majority of women who received a method before discharge had a sterilization $(81 \%)$, with the remainder receiving oral contraceptives (15\%) and Depo-Provera (4\%).

Family planning services are usually offered in the outpatient areas of health units and have little or no relationship with the services that are provided in the hospital or even with the in-patient areas of the same health unit. This makes it difficult to meet the needs of the three-quarters of women in the DR who deliver in public health centers. Further, family planning services are usually only offered three or four hours per day during the mornings. Since service providers in the in-patient areas often do not provide counseling to their clients during their stay.

One half of the women interviewed in health centers that had had a delivery in the previous six months reported using a contraceptive method; methods included pills (37\%), female sterilization (37\%), Depo-Provera (15\%), and condoms (8\%). Less than one percent mentioned 
using LAM, although 12 percent of those who were not using a contraceptive said that they did not need a method because they were breastfeeding.

Figure 2: Cumulative probability of starting contraceptive use by postpartum month, by timing of information on family planning

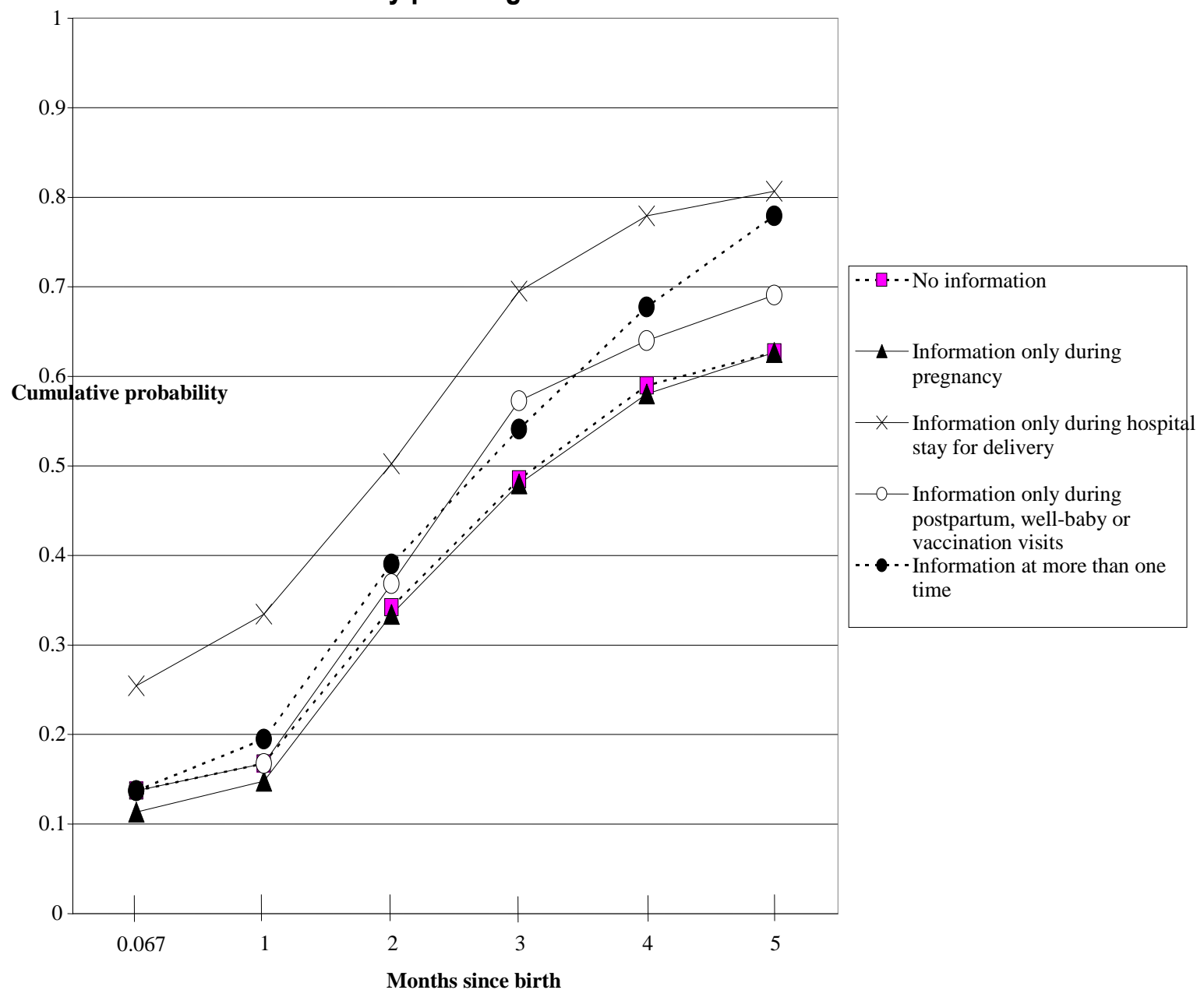

The probability of using a contraceptive method increases with time since delivery and with receiving family planning information during the hospital stay and during post-delivery visits, as shown by Figure 2. A logistic regression that controlled for age, education, marital status, exclusive breastfeeding, return of menses, parity, and family planning counseling at different times found that counseling during antenatal care did not affect the likelihood of a woman using a contraceptive in the six months postpartum, whereas counseling during a hospital stay increased the probability by 73 percent, and counseling during post-delivery visits increased it by 110 percent (See appendix 1). Other factors that increased the likelihood of contraceptive use were being married or cohabiting, stopping exclusive breastfeeding, return of menses, parity, and having some college education. 
At least six in 10 women who began using a contraceptive method in the first six months after delivery received their method from a public source, mainly from the hospital where they delivered $(39 \%)$ or from a public health center $(27 \%)$. A further 27 percent received their method from a pharmacy and six percent from a private physician or in a private clinic. Public hospitals were by far the largest source of sterilization.

Intention to use: As can be seen in Table 6, nearly all women who were not already using a method said they would like to start using one in the first six months postpartum, preferably not long after the delivery. The methods that women in antenatal care and at hospitals most often intended to use were the pill (around 30\% of the respondents), Depo-Provera (about 25\%) and female sterilization (around 26\%). In contrast, 40 percent of the women at health centers in the first six months postpartum mentioned pills, 29 percent Depo-Provera, and 11 percent sterilization. This distribution probably reflects the fact that many women receive their sterilization immediately after delivery in the hospital.

Only about one in four women who wanted to use a method in the future was told during antenatal care or during her hospital stay where to obtain one. When asked, however, most women knew where to obtain a method; the sources most often mentioned were the health center where the interview took place and pharmacies.

Unmet need: An unmet need is both a measure of the risk of an unplanned pregnancy and a summary indicator of access to and information about contraceptive methods (RAND 1998). Women in the first six months after a delivery were considered to have an unmet need when they both did not want another pregnancy at all, or within the next two years, and were not using a contraceptive method (including women who said that they were not using any method because they were breastfeeding). With this definition, 45 percent of women interviewed in the six months following a delivery had an unmet need - substantially higher than the 11 percent estimated by the ENDESA 2002 for all women. This underlines the importance of emphasizing counseling and providing methods for postpartum women. Unmet need in the postpartum period was particularly high among those under 20 years (49\%), and much lower (33\%) for those over 34 years. Virtually all (93\%) of women with an unmet need said that they would like to use a method, and 39 percent would have liked to be using one already, or to start using at once. The main reasons given by the 61 percent wanting to delay starting a method were because they were not at risk of becoming pregnant, either through not having sexual relations (29\%) or being amenorrheaic $(21 \%)$, or having recently delivered (18\%). 
Table 6: Distribution of women not using contraception by intention of use in the future, method desired and knowledge of method sources by type of respondent (\%)

\begin{tabular}{|c|c|c|c|}
\hline \multirow[b]{2}{*}{ VARIABLES } & \multicolumn{3}{|c|}{ TYPE OF RESPONDENT } \\
\hline & $\begin{array}{c}\text { Pregnant } \\
\text { women } \\
(\mathbf{n}=\mathbf{2 , 8 6 5})\end{array}$ & $\begin{array}{c}\text { Women before } \\
\text { discharge after } \\
\text { delivery } \\
(n=773)\end{array}$ & $\begin{array}{l}\text { Women in the } \\
\text { first six months } \\
\text { after delivery } \\
(\mathbf{n}=750)\end{array}$ \\
\hline Would like to use methods in the future & 97.0 & 95.6 & 91.7 \\
\hline \multicolumn{4}{|l|}{ Desired method } \\
\hline Pills & 29.5 & 27.7 & 39.8 \\
\hline Depo-Provera & 25.4 & 24.2 & 28.5 \\
\hline Female sterilization & 24.5 & 27.3 & 11.0 \\
\hline NORPLANT & 7.9 & 7.0 & 9.4 \\
\hline IUD & 5.4 & 5.7 & 5.6 \\
\hline Condoms & 1.7 & 0.2 & 1.6 \\
\hline Vasectomy & 0.7 & -- & 0.0 \\
\hline LAM & 0.4 & 0.2 & 0.0 \\
\hline Other natural methods & 0.4 & -- & 0.8 \\
\hline \multicolumn{4}{|l|}{ Time they would like to start use: } \\
\hline Immediately after delivery & 61.5 & 7.8 & 37.9 \\
\hline After less than one month & -- & 23.3 & 3.4 \\
\hline $1-2$ months after delivery & 11.1 & 25.8 & 8.4 \\
\hline 2-4 months after delivery & 9.9 & 23.5 & 15.7 \\
\hline 4-6 months after delivery & 1.5 & 3.2 & 0.9 \\
\hline At six or more months after delivery & 2.7 & 3.0 & 5.7 \\
\hline After stopping breastfeeding & 2.1 & 0.4 & 3.6 \\
\hline At the return of menses & -- & -- & 16.6 \\
\hline At another moment & 7.1 & 6.3 & 4.0 \\
\hline Does not know & 4.0 & 6.6 & 3.7 \\
\hline Were told where to obtain the method & 35.6 & --- & -- \\
\hline Were referred for method & 20.8 & 15.7 & -- \\
\hline \multicolumn{4}{|l|}{ Know where to obtain the method: } \\
\hline At the place where the interview took place & 69.9 & 64.0 & 70.2 \\
\hline In the hospital where she delivers & 10.1 & -- & -- \\
\hline $\begin{array}{l}\text { At health center where she receives } \\
\text { postpartum follow-up care }\end{array}$ & 2.8 & 16.2 & $\overline{--}$ \\
\hline At another public health center & -- & -- & 16.3 \\
\hline Private clinic & 11.2 & 10.9 & 12.3 \\
\hline Pharmacy & 37.2 & 18.3 & 36.2 \\
\hline Other & 20.9 & 32.6 & 15.2 \\
\hline
\end{tabular}




\section{Organization of Services}

Schedules: According to providers and program managers, 78 percent of the 59 health units visited offer family planning services five days per week. Outpatient services (90\%) were more likely to offer services for five days than hospitals (73\%), and only 38 percent of hospitals offered services in the morning and afternoon, compared to 79 percent of outpatient services. Most of the units that do not offer services for the full day offer them only in the mornings and so women who are discharged from hospitals at noon or early afternoon would need to return the following day to receive a method.

\section{Box 3. "The doctor asks me why I keep quiet": Privacy conditions are worse in large hospitals than in small hospitals}

A user explained that during her counseling she had not received enough information to choose a contraceptive method because there were too many people listening and she could not answer the doctor's questions: "The doctor asks me why I keep quiet. And I respond that I do not like to answer any questions in front of others, unless they are the doctor." Lack of privacy is common in maternity wards.

Even when the units in the national and regional hospitals were more spacious than those of the provincial and municipal hospitals, the privacy and hygiene conditions found in larger hospitals were usually worse. The large hospitals were so crowded that many beds in the rooms were occupied by two women and their babies at the same time. Moreover, beds were placed immediately next to one another, with no separation whatsoever. Taking into account that rooms in these large hospitals had between 10 and 16 beds, one could find 32 women in one room, with no air conditioning. This lack of privacy affected not only family planning counseling (usually given at bedside), but the clients' overall comfort. Because clean blankets were seldom available, women were commonly lying naked or covered with a piece of cloth on a bare, dirty mattress while others watched.

In smaller hospitals, the rooms had between 4 and 8 beds, and these were never shared by two women. As in larger hospitals, there were no divisions between beds (although some hospitals had movable screens that could be used for this purpose), but it was easier for the provider to give counseling without anyone else hearing. Smaller hospitals also had a limited number of blankets available, but the research team noticed that health providers in these establishments were more attentive with women and tried to help them find something to cover themselves, asking them, for example, to keep the blanket that they had used in another room.

Auditory and visual privacy: Ninety-five percent of the hospitals provide family planning information to women attending for delivery, in a variety of locations where the women are likely to be. Ninety percent of the outpatient health centers provided counseling in family planning, mostly in medical offices and the waiting area, although one quarter did so in the community room. Counseling should take place in an area that offers privacy; in practice, however, hospitals did not appropriately protect clients' privacy, as can be seen in Table 7. In outpatient health centers the situation is not much better; about half were observed to offer counseling in places that did not offer auditory or visual privacy. 
Table 7: Auditory and visual privacy in the areas where family planning counseling is offered (\%)

\begin{tabular}{||l|c|c||}
\hline Places in which counseling is offered & $\begin{array}{c}\text { Offer auditory } \\
\text { privacy }\end{array}$ & $\begin{array}{c}\text { Offer visual } \\
\text { privacy }\end{array}$ \\
\hline Pre-delivery area $(\mathrm{n}=6)$ & 83 & 83 \\
\hline Postpartum ward $(\mathrm{n}=15)$ & 33 & 27 \\
\hline In the rooms $(\mathrm{n}=16)$ & 31 & 19 \\
\hline Medical office $(\mathrm{n}=16)$ & 69 & 63 \\
\hline Counseling office $(\mathrm{n}=9)$ & 44 & 33 \\
\hline
\end{tabular}

\section{Availability of contraceptive methods}

In 1997, the National Family Planning Program experienced a decrease in international donations of contraceptives and began to purchase them, which has led to frequent contraceptive stock-outs (Agudelo, Jiménez, et al. 2005). Other availability problems have been identified, such as the limited range of methods available in public health facilities (Miller et al 2002) and the logistical problems that affected the program (DAIA Diagnostic 2005). Since 2004, SESPAS has been able to include a line item in the national budget for the purchase of contraceptives for areas that do not receive international donations. To help achieve continuous availability of methods, the National Contraceptive Security Committee (Comité para la Disponibilidad Asegurada de Insumos Anticonceptivos, DAIA) was created in April 2005 with representation of government agencies, non-governmental agencies, the private sector and international cooperation agencies (Agudelo, Jiménez, et al. 2005).

Despite the efforts made recently, visits to 59 health units showed that 46 (88\% of hospitals and $74 \%$ of health centers) had had contraceptive method stock-outs in the preceding three months. Similarly, on the day of the visit, one quarter of the units were out of stock of one or more of the methods routinely offered. Further, many did not offer the full range of methods: 13 health centers did not provide the IUD and 16 were not providing spermicides. As Table 8 shows, the methods most frequently out of stock were condoms (53\%) and pills (28\%).

Table 8: Percentage of health units visited that have had stock-outs of different contraceptive methods and IEC materials

\begin{tabular}{||l|c||}
\hline \multicolumn{1}{|c|}{ Methods } & $\% *$ \\
\hline Condoms (n=57) & 53 \\
\hline Natural method brochures $(\mathrm{n}=46)$ & 30 \\
\hline Oral contraceptives $(\mathrm{n}=57)$ & 28 \\
\hline LAM brochures $(\mathrm{n}=40)$ & 28 \\
\hline Vaginal spermicides $(\mathrm{n}=43)$ & 26 \\
\hline Depo-Provera $(\mathrm{n}=57)$ & 18 \\
\hline IUD $(\mathrm{n}=46)$ & 4 \\
\hline \hline
\end{tabular}

* Percentage estimated from the number of centers that routinely offered the method 
Satisfaction with services and quality of care

Ninety-six percent of respondents said the service providers had treated them well or very well, and only 3 percent said they had been badly treated. Likewise, 95 percent said they would recommend the services to a friend. Despite these positive perceptions and attitudes of clients, there is room for improvement. Four out of 10 pregnant women were not able to spontaneously mention any of the emergency symptoms that indicate the need for immediate medical care; this is perhaps explained by the short time spent with providers. According to Miric (2006), consultations "seldom last more than five minutes," barely enough time to indicate lab tests, weigh them, measure uterine height and take their blood pressure. The study also showed that many women leave the hospital after a delivery without adequate information about how to take care of themselves: one-third were not able to spontaneously mention post-delivery warning signs.

\section{Box 5. Many postabortion care cases are treated within an hour of arriving at the hospital, but others have to wait more than five hours}

Forty-four percent of the postabortion care women interviewed were seen by a health provider within the first hour after arriving at the hospital, but 48 percent had to wait more than three hours. Others had to wait more than 10 hours before being treated.

One woman went to the hospital seeking care for abortion complications. She arrived at 1:00 pm and was hospitalized that same afternoon. She was put in a common room with other women in need of postabortion care. Close to 7:00 pm, a doctor came to see them and told them that they were not going to be seen until midnight, because many $\mathrm{C}$-sections were pending. At 9:00 pm the woman was taken to the operating room, but was soon taken out because there was another emergency. No doctor came to see her during the night and she woke up bleeding in a bed without sheets. At 11:00 am she had a curettage, after which, under the effects of the anesthesia, she spent several hours in the curettage room, only partially covered by a piece of a blanket on a blood-stained bed.

\section{Postabortion Care}

SESPAS statistics show that 20 percent of maternal deaths in the Dominican Republic are related to abortion complications (Cáceres 1998). Even so, the MOH does not include postabortion care within its the reproductive health policy to decrease maternal mortality. Since 2002, however, the $\mathrm{MOH}$, with assistance from the USAID-funded CONECTA project, has been seeking to improve the quality of obstetric services in the hospitals with the largest volume of services, including the introduction of manual vacuum aspiration (MVA) and a comprehensive model for postabortion care (PAC). As a result, over 90 percent of cases are treated with this technique at the San Lorenzo de los Minas maternity (one of the largest in the country). Another result of the CONECTA project has been that at least three of the seven SESPAS national and regional hospitals have adopted a PAC package of services as part of a National Obstetric Emergency Care package.

Family planning counseling and information: According to the National Family Planning Guidelines (SESPAS 2007), family planning counseling should be provided to PAC clients. However, PAC clients received very limited information and counseling (see Figure 4), and more than one-third (37\%) of clients interviewed would have liked to receive more information before leaving the hospital. 


\title{
Figure 4: Percentage of PAC clients who received family planning counseling and information on the return of fertility before discharge from the hospital
}

\author{
Return of fertility \\ 25 \\ Importance of waiting before next pregnancy \\ 25 \\ FP counseling \\ 12 \\ Future reproductive intentions \\ 7 \\ 0 \\ 20 \\ 40 \\ 60 \\ 80 \\ 100
}

Contraceptive use before the last pregnancy: Seventy-two percent of PAC clients said they had not been using a contraceptive method when they became pregnant. About half of these (36\% of all PAC clients) had wanted to be pregnant; the other half said that the pregnancy was unplanned and they would have preferred not to get pregnant or to get pregnant at a different time. These women mentioned fear of side-effects (25\%), the belief that the risk of a pregnancy was very low (13\%), infrequent sexual relations (7\%), and that they did not know methods (4\%) as reasons for not having used family planning.

Delivery of methods during hospital stay: Ninety-one percent of PAC clients left the hospital without a contraceptive method, even though 87 percent of these women would have liked to receive one before discharge. Three-quarters of these women said the provider never offered them a method. Ten percent said the provider had suggested waiting some time before starting use of a method and eight percent said the hospital did not have methods available.

Intention to use methods in the future and known sources of supply: Eighty-eight percent of PAC clients who did not receive a contraceptive before discharge said they intended to use a method in the following six months, but only 17 percent of these were referred by health providers to a place where they could get their preferred method. As can be seen in Table 9, the majority of these women said they would like to use a temporary method.

Even though most PAC clients did not receive information on contraceptive methods, 90 percent of them knew where to get a method when they need it. Of these, 67 percent mentioned the health unit where they were interviewed, 39 percent mentioned a pharmacy, 16 percent a private clinic, and 11 percent the health center for the PAC follow-up visits. 
Table 9: Contraceptive preferences of PAC clients who did not receive a method before hospital discharge and would like to use a method in the next six months (\%)

\begin{tabular}{||l|c||}
\hline \multicolumn{1}{|c|}{ Preferred method } & $\begin{array}{c}\text { \% } \\
(\mathbf{N = 1 3 0})\end{array}$ \\
\hline Pills & 43 \\
\hline Depo-Provera & 26 \\
\hline Norplant & 8 \\
\hline Female sterilization & 6 \\
\hline IUD & 6 \\
\hline Condoms & 1 \\
\hline Did not know & 10 \\
\hline
\end{tabular}

Unmet need: Women attending for postabortion care are a population that family planning programs have not been able to reach in the DR. Of the 162 women interviewed before discharge from a hospital after postabortion care, 65 percent did not want to have children in the next two years, with 16 percent not wanting any more children. Most of these women wanted a temporary method to space their next pregnancy.

Methods received before hospital discharge: Of the 15 postabortion clients who received a method before their discharge, four received pills, one received the IUD, and one was sterilized. The rest did not specify which method they received. All the women who received the pill got information on how to take the pill, what to do in case they forgot one, and the possible side effects. By contrast, the woman who got the IUD and the woman who was sterilized said that they did not receive any information about the method.

Availability of contraceptives: Postabortion care can be provided in primary health care units with appropriately trained providers (Population Council 2001). However, in the public sector in the DR, PAC is offered almost exclusively at hospitals. Of the 59 health units sampled, only the 40 hospitals and one health center offered PAC services. According to WHO, in the absence of complications (mainly infections) all contraceptive methods can be offered in the postabortion period; the IUD and female sterilization should not be provided in the presence of complications (WHO 1999). Only 30 percent of the hospitals sampled made contraceptive methods available to postabortion women before hospital discharge. Of these, half (54\%) had only one or two methods available, most commonly pills, IUDs and condoms; only six hospitals had three or more methods available.

All the hospitals visited had at least one method which not offered to postabortion women, despite it being available in the maternity ward or outpatient services. This implies that the main barriers to offering a full range of methods for postabortion women are the absence of mechanisms for outpatient referrals, and the lack of a system for routinely providing information and offering methods to PAC clients.

Training of providers: Most of the providers that provide postabortion services said they had received some training in PAC (Table 10). Even though MVA was only recently introduced in 
the DR, 45 percent of the providers had been trained in its use, nearly as many as trained in dilation and curettage (D\&C). In fact, 36 of the 64 doctors that implemented uterine evacuation procedures said they most frequently used MVA.

Table 10: Proportion of PAC providers trained by topic

\begin{tabular}{||l|c||}
\hline \multicolumn{1}{||c|}{ Topics } & $\begin{array}{c}\text { \% } \\
\text { (N=192) }\end{array}$ \\
\hline Training in at least one PAC topic & 91 \\
\hline Pain management in PAC clients & 75 \\
\hline How to diagnose an incomplete abortion/a postabortion complication & 70 \\
\hline Counseling for postabortion women & 68 \\
\hline Contraception for postabortion women & 64 \\
\hline Care of repeat abortion cases & 63 \\
\hline Dilation and curettage (D\&C) & 54 \\
\hline Laboratory tests for incomplete abortions and abortion complications & 52 \\
\hline Manual vacuum aspiration (MVA) & 45 \\
\hline Electric vacuum aspiration & 16 \\
\hline
\end{tabular}

Quality of and satisfaction with services: Women who had received PAC were asked to rate the service during their stay. Eleven percent said they had been treated very well and 79 percent well. Only two percent rated the treatment as bad or very bad. Similarly, 86 percent of the women said they would recommend the service to a friend or relative and only 11 percent said they would not recommend it.

Despite women's positive views, eight out of 10 did not receive drugs to relieve pain before the emergency procedure and only one-half received some pain relief afterward. Only 40 percent were told the name of the procedure they had undergone and 20 percent did not receive any information on emergency signs and symptoms signaling the need to return immediately to the hospital. Less than half received advice for what they should do during the postabortion period, such as the time they should wait before returning to their routine activities, avoiding aspirin, and abstaining from sexual relations for some time. What clients reported contrasts sharply, however, with what providers say they tell their clients: 62 percent said that they always or often provided pain relief, and 80 percent said that they gave information on danger signs (see Table 11).

\section{Table 11: Pain relief and information during postabortion care according to providers and users}

\begin{tabular}{||l|c|c||}
\hline \multicolumn{1}{|c|}{ Type of pain management activity or information } & $\begin{array}{c}\text { \% women who } \\
\text { said they received } \\
(\mathrm{n}=162)\end{array}$ & $\begin{array}{c}\text { \% providers } \\
\text { who said they } \\
\text { gave (n=192) }\end{array}$ \\
\hline Pain relief drugs before the procedure & 14 & 62 \\
\hline Pain relief drugs after the procedure & 50 & -- \\
\hline Information about the name of the procedure & 60 & 93 \\
\hline Information about emergency signs and symptoms & 21 & 84 \\
\hline Information about taking care of herself after discharge & 46 & 90 \\
\hline
\end{tabular}




\section{Prevention of Mother-to-Child Transmission of HIV and syphilis}

\section{Background}

Since 2002, the MOH and the General Direction for the Control of Sexually Transmitted Infections and AIDS (DIGECITSS) have been implementing the National Program for the Reduction of the Vertical Transmission of HIV/AIDS (PMTCT), which includes sexual education, HIV voluntary testing and counseling, HIV antiretroviral therapy (ART) for children and mothers, C-sections to HIV+ women, supplementary feeding, and follow-up of program clients. Although there is no national program for the prevention of maternal syphilis, the official service delivery guidelines require that all women are tested for syphilis in the first 20 weeks of pregnancy (SESPAS-CERSS 2001).

\section{PMTCT services}

HIV and PMTCT counseling was offered to all antenatal care women in half (53\%) of the health centers sampled, and voluntary HIV testing was offered in 37 percent. Eighty-three percent of the 40 hospitals visited conduct at least some PMTCT activities for women in delivery care, including counseling (58\%), infant feeding with formula (51\%), C-sections (51\%), antiretroviral treatment for mothers (49\%) and counseling on infant feeding (33\%). Thirty-five percent of the hospitals visited conducted one or two of these activities, and 48 percent conducted three or more.

Family planning counseling providers were asked if they discussed HIV/AIDS during counseling. Seventy-six percent of providers in the Ob-Gyn wards and 87 percent of the providers in outpatient services said they did, most often giving the message that condoms are the only family planning method that protects against HIV/AIDS (84\% of outpatient providers and $70 \%$ of Ob-Gyn ward providers).

\section{Readiness to provide services}

Key aspects for PMTCT services are the availability of trained staff, HIV tests and antiretrovirals. Of the 40 hospitals visited, 39 had supplies and staff to offer the HIV test and all 40 had supplies and staff to provide syphilis tests. However, not all providers were aware of their existence. Twenty-nine percent of providers in the maternity and Ob-Gyn wards of the hospitals visited said there were no PMTCT program activities at their hospitals and 4 percent did not know that such a program existed.

Availability of staff and supplies to provide other STI services were much lower: only about 80 percent could provide the Pap test, about 70 percent had the staff and supplies to provide gonorrhea testing, and only about half had the staff and supplies (50\% and 40\%) to conduct Chlamydia and Candida tests.

Antiretrovirals for adults were available in 60 percent of the hospitals; about half had antiretrovirals for babies, 42 percent had treatment for syphilis, and 26 percent had drugs for other STIs. In all these cases, a larger proportion of health unit directors reported having these supplies available than what the observers actually found in stock. 
Voluntary counseling and testing: All women who were attending antenatal or delivery care in were asked if they had received any messages on HIV, if providers had taken blood samples, if they knew the name of the tests conducted and if they had had an HIV/AIDS and/or a syphilis test. Fifty-eight percent of antenatal clients had been told about HIV, and 12 percent of women interviewed during delivery had received this information. Practically all (95\%) had been told that, without appropriate care, the infection could be transmitted from mother to child, that condom use reduces the risk of acquiring the virus, and that sexual promiscuity (their own or their partners') is a risk factor. Of these messages, condom use was the one that women were most likely to remember spontaneously (48\% of women in antenatal care and $33 \%$ of women interviewed after their delivery). Provision and awareness of blood tests was high (see Table 12). More than 94 percent of providers in outpatient services said they recommended HIV/AIDS tests to all antenatal care clients, and a slightly lower proportion (89\%) mentioned they recommended syphilis tests. Urine and other blood tests were mentioned by 93 and 96 percent of providers, respectively.

In addition to the high coverage of HIV tests in antenatal care, 37 percent of women interviewed before discharge after delivery said that they had had a HIV/AIDS test during their hospital stay; 79 percent of these had previously received the test during antenatal care, a repetition that is not recommended in the service delivery guidelines.

Table 12: HIVIAIDS and syphilis testing during pregnancy, by type of respondent (\%)

\begin{tabular}{|c|c|c|c|}
\hline \multirow{3}{*}{ Type of test } & \multirow[b]{2}{*}{ Total } & \multicolumn{2}{|c|}{ Type of respondent } \\
\hline & & $\begin{array}{l}\text { Antenatal } \\
\text { clients }\end{array}$ & Delivery clients \\
\hline & $\begin{array}{c}\% \\
(n=3,832)\end{array}$ & $\begin{array}{c}\% \\
(\mathrm{n}=2,965)\end{array}$ & $\begin{array}{c}\% \\
(\mathrm{n}=867)\end{array}$ \\
\hline Had a blood sample taken ${ }^{\mathrm{a}}$ & 89 & 86 & 98 \\
\hline Know the type of test conducted ${ }^{b}$ & 95 & 95 & 95 \\
\hline HIV/AIDS test given $^{\mathrm{c}}$ & 94 & 95 & 96 \\
\hline Syphilis test given $^{\mathrm{c}}$ & 72 & 71 & 73 \\
\hline Received the test results ${ }^{\mathrm{c}}$ & 94 & 94 & --- \\
\hline
\end{tabular}

${ }^{a}$ Percent estimated over total number of women interviewed

${ }^{\mathrm{b}}$ Percent estimated over women that had a blood sample taken

${ }^{\mathrm{c}}$ Percent estimated over women who were told what test had been conducted

Perceptions of HIV risk: All respondents were asked if they thought they were at risk of acquiring HIV. Seven out of 10 women did not feel at risk, a proportion similar to that observed in the ENDESA-96. Perceived risk was slightly higher among women at hospitals after a delivery $(28 \%)$ and among those visiting health centers in the first six months after a delivery or an abortion (24\%) than among women receiving antenatal (22\%) or postabortion care (20\%). 


\section{Contraceptive services for HIV + women attending Integral Care Units}

Avoiding unplanned pregnancies among women living with HIV/AIDS (WLHA) is one of the four basic strategies recommended by WHO to prevent mother-to-child transmission of HIV/AIDS $^{2}$. This requires that WLHA have access to contraception and staff trained in the interactions between contraceptives and HIV/AIDS.

Family planning counseling for HIV + women in Integral Care Units (ICUs): Providers in the ICUs visited were asked if they provided family planning counseling and services to WLHA. Only 36 percent said they provided contraceptive counseling and of these, only 41 percent offered these contraceptive services also. These providers were well informed about the importance of condoms and the risks of breastfeeding for children of WLHA. All of these providers said that they always recommend consistent condom use; 64 percent recommend not breastfeeding or using LAM; and 57 percent mentioned that antiretrovirals may reduce the effectiveness of hormonal contraception.

WLHA have the right to have or not have children, and through the use of prophylaxis and ART during pregnancy and delivery, safe birth practices and the substitution of maternal milk with formula, WLHA who want to have children can minimize the risk of transmitting the virus to their child. Thus, service providers have the responsibility of helping women achieve their reproductive goals in the safest possible way. Nevertheless, a large proportion of the providers interviewed believe that WLHA should not have children - one in three providers $(36 \%)$ who provide family planning counseling to WLHA say that in their sessions they made special emphasis on the use of sterilization.

\section{Table 13: Recommendations of family planning counselors in ICUs to WLHA (\%)}

\begin{tabular}{||l|c||}
\hline \multicolumn{1}{||c||}{ Recommendations } & $\begin{array}{c}\text { \% } \\
(\mathbf{n = 1 4 )})\end{array}$ \\
\hline Always use condoms & 100 \\
\hline Not to breastfeed or use LAM & 64 \\
\hline Careful use of pills with ART & 57 \\
\hline Special emphasis on sterilization & 36 \\
\hline
\end{tabular}

${ }^{a}$ Percent estimated over family planning counselors in ICUs who said they gave counseling to WLHA

WLHA receive most of their medical care in integral care units (ICU), where ideally they should receive family planning counseling and the contraceptive methods they desire. However, not all WLHA attending ICU had access to FP: only 54 percent of these women said they had received family planning counseling and 21 percent had been asked if they wanted to use a method.

\footnotetext{
${ }^{2}$ The other three recommended actions are: 1) prevent HIV infections among all persons, but particularly among young women; 2) antiretroviral therapy, safe delivery practices and the use of maternal milk substitutes; and 3) care and support of WLHA, their children and their families (WHO 2002a and OMS 2002b).
} 
Contraceptive use among ICU clients was high, even though a high proportion of women had discontinued use of their methods. Of 161 women interviewed at ICUs, 142 had used a contraceptive method at some point in their lives and 100 said they were currently using one. Almost half (45\%) of the women who were currently using a method obtained it at the hospital during their last delivery, one in four $(23 \%)$ obtained it in the ICU, and one in five (19\%) in a pharmacy (all of them condom users).

Female sterilization (used by 67 of the women) and the condom (used by 37 women) were the two methods preferred by WLHA; it should be mentioned that 17 of these reported dual use of sterilization and condoms and two of condoms and other methods. Two women said they and their partner used vasectomy, and four women used other methods. Twenty of the 54 WLHA who were not using a method said they would like to be using one; of these, 13 were not doing so because they did not have a partner or were not having sexual relations; four were pregnant, and three wanted to use a method but their husbands had not allowed them. Women who did not want to use a contraceptive said that they did not have a stable partner $(48 \%)$, that they did not have sexual relations $(41 \%)$, or that they or their husband were no longer fertile $(12 \%)$.

\section{RECOMMENDATIONS FOR IMPROVING THE QUALITY OF SERVICES}

The results have shown that family planning services were linked to antenatal, delivery and postpartum care in most of the health units visited. These results have been shared and discussed with MOH directors of maternal and child health services (DIGEMIA), and with the directors of planning and of the program to prevent mother-to-child transmission of HIV in the HIV/STI department (DIGECITSS). They have also been shared with the USAID mission, CONECTA, the Reproductive Health Division of the Dominican Institute of Social Security, and the UNFPA representative. DIGECITSS and DIGEMIA are now considering some of the needs identified when planning their budget for the next fiscal year.

Most providers had received training, especially in health care centers and outpatient services in hospitals, and family planning counseling was well established in antenatal care. However, 
although three-quarters of women would have liked to leave hospital with a contraceptive method, only 12 percent received one before discharge, and a large proportion of those who wanted a method did not receive it later; by six months, only $47 \%$ of women visiting outpatient services reported using a method. Thus, a strong limitation was the lack of linkages between counseling during antenatal care and the provision of methods at the hospitals and maternities after delivery. While the National Family Planning Service Delivery Guidelines indicate that both activities should take place, they do not describe how these services should be provided and who should provide the methods at hospitals; nor do they recommend how to care for women during the extended postpartum period at health centers. The National Family Planning Service Delivery Guidelines should be modified so that they underline the need to provide counseling to all women who have had a delivery and to offer and provide them contraceptive methods when desired, and that clear referral guidelines are outlined.

Most hospitals offered services during limited time periods (usually Monday to Friday, often only in the morning), while women were discharged mostly in the afternoon Providers in health centers and outpatient services should be trained to identify women in the extended postpartum period and to offer them family planning services. Contraceptive stock-outs were another limitation, which were more frequent at hospitals than at health centers.

PMTCT program components (including prophylaxis and ART, safe birth practices and substitute formula for WLHA) need to be strengthened, since one-third of the providers in ObGyn wards were not aware of the existence of the program. PMTCT activities have focused on VCT for pregnant women, but have not focused on systematically making sure that women in integral care units receive family planning counseling and methods. Further, there is a need for training service providers at ICUs about the interactions between ART and contraceptive methods, about use of the IUD among WLHA, and about the reproductive rights of WLHA, since they are not aware of these issues or have misperceptions.

Based on this project's findings, key recommendations to improve postpartum and postabortion family planning services include:

- Use the opportunity offered by the dissemination of the 2007 National Family Planning Service Delivery Guidelines for presenting key results of this study and design activities to improve postpartum and postabortion services.

- Design a brochure for pregnant and postpartum women that clearly presents the advantages of spacing the next pregnancy, contraceptive options available for women in the postpartum period, and what a woman needs to do to obtain the services.

- Design an information system to help identify women who decide during antenatal care that they want to start using an IUD or undergo sterilization before discharge.

- Establish the following as routine services in maternities and Ob-Gyn wards: family planning information for all women; offer methods to all women; family planning counseling for all women interested in getting a method; and delivery of the chosen method to all women who want one.

- Inform all postpartum women interested in using a hormonal method of its contraindications. If methods are distributed before hospital discharge, give clear, written indications on when 
to start their use. If methods are not distributed in the hospital, give a written referral stating when and where to obtain them.

- Design brief brochures explaining everything that women in the postabortion and postpartum period need to know regarding emergency symptoms, resumption of fertility and sexual activity, contraception, and follow-up care.

- Providers at maternities and Ob-Gyn wards should receive a brief refresher about the new essential contraceptive practice guidelines, including contraceptive contraindications for postpartum and breastfeeding women, the resumption of fertility after childbirth and an abortion, and follow-up care.

- Review the counseling curricula for PAC clients, as providers need to be more aware of women's emotional and physical health needs.

- In health centers and outpatient services, providers should systematically screen for family planning needs and services; the Population Council's Systematic Screening technique can be adapted for these purposes.

- Study the feasibility of establishing joint care for mothers and children during the first six months after birth.

Key recommendations for improving PMTCT services include:

- Inform all pregnant women who have a blood sample taken which tests will be conducted.

- Design and establish a mechanism to allow providers to identify women who have already had voluntary counseling and testing during antenatal care and the result of the test, while maintaining women's right to confidentiality.

- Increase the linkages between family planning and services at Integral Care Units, either by arranging frequent visits by family planning providers to the ICU or by training the ICU providers to screen for family planning needs and provide contraceptive technology or refer to contraceptive service delivery sites.

- Provide refresher training to family planning providers that give services to women living with HIV/AIDS (WLHA) on the interactions between contraception and antiretrovirals, and include general information about contraception and HIV/AIDS, including women's sexual and reproductive rights, such as the right to reproduce and the right to choose the method they desire without pressure from the provider.

- Use the waiting rooms at the ICUs to show family planning videos and have brochures on the topic available. 


\section{REFERENCES}

Agudelo, Juan; Erin Hasselberg, Ramon Jiménez,Eleodoro Pérez, y Viriato Acosta. 2005. Diagnóstico sobre la Disponibilidad Asegurada de Insumos Anticonceptivos (DAIA) en República Dominicana Analysis on the Reliable Availability of Contraceptive Products in the Dominican Republic). SESPAS, CONAPOFA, USAID/DELIVER y UNFPA. Available on the Internet at: www.conapofa.gov.do/investigaciones_sociodemograficas/InvestigacionA.pdf

Amnistía Internacional. 2006. El VIH/SIDA y los derechos humanos en la República Dominicana y Guyana [HIV/AIDS and human rights in the Dominican Republic and Guyana]. May. Available on the Internet at: http://web.amnesty.org/library/index/eslamr010022006

Betts, Claudio. Evaluación del Programa Nacional de Reducción de la Transmisión Vertical del VIH/SIDA en República Dominicana [Evaluation of the National Program for Reducing the Vertical Transmission of HIV/AIDS in the Dominican Republicl. CPRESIDA, SESPAS/DIGECTISS y UNICEF, First Edition, September 2005.

Billings; Deborah. Investigaciones en acción: atención post-aborto en cuatro países de América Latina [Research in Action: Postabortion Care in Four Latin American Countries]. IPAS, 2005. Available on the Internet at:http://www.ipas.org/publications/es/LAC4PAC_S06_es.pdf

Blanco, Jorge Humberto. 2005. Personal communication. September 8.

Borda, M., V. Simán de Betancourt, and B. Winfrey. 2004. "República Dominicana. Segmentación de Mercado de Planificación Familiar. Análisis de Tendencias: 1996-2002 [Dominican Republic: Market segmentation of Family Planning: Anlysis of trends 1996-2002]." PowerPoint presentation.

Bruce, Judith. Fundamental Elements of the quality of Care: A simple Framework. Population Council. originally published in Studies in Family Planning, Vol. 21, No. 2, March/April 1990, pp. 61-91 Available on the Internet at: http://www.pocouncil.org/qoc/qocfundamentals/index.html

Cáceres, Francisco. 1998. La Mortalidad Materna en la república Dominicana: El Caso del Distrito Nacional [Maternal Mortality in the Dominican Republic: The Case of the National District]. Instituto de Estudios de Población y Desarrollo (IEPD)/PROFAMILIA, Fondo de Población de las Naciones Unidas. Segunda Edición, Santo Domingo, República Dominicana.

CONAPOFA.2005. "República Dominicana. Diagnóstico Sobre Disponibilidad Asegurada de Insumos Anticonceptivos [Dominican Republic: Analysis of the Secure Availability of Contraceptive Products"

Consejo Nacional de Población y Familia (CONAPOFA). 2007. Evaluación de los Servicios de salud reproductiva [Evaluation of reproductive health services]. Boletín Informativo No. 9, January-March.

Dewey, Kathryn G. and Roberta J. Cohen. "Does birth spacing affect maternal or child nutritional status? A systematic literature review," Maternal \& Child Nutrition 3 (3), 151-173, 2007.

Dominican Republic National Council on Social Security. Available on the Internet at: http://www.cnss.gov.do.

"El impacto del VIH y SIDA en las mujeres [the impact of HIV and AIDS on women]," Hoy Newspaper, Monday March 5, 2007. 
Family Health International (FHI). 1996. "Contraceptive update: Research confirms LAM's effectiveness," Network Volumen 17, No. 1. Autumn.

FHI. 2007. "Asesoramiento para el uso de métodos anticonceptivos [Assessment for the use of contraceptive methods]." Available on the Internet at: http://www.fhi.org/sp/RH/FAQs/famplancounsel_faq.htm. .

FHI. 2007b. "Contraception after pregnancy," Contraceptive Technology and Reproductive Health Series. Available on the Internet at: http://www.fhi.org/training/en/modules/AFTER/default.htm.

FHI. 2001. "Las mujeres VIH-positivas tienen necesidades diferentes [HIV-positive women have different needs," Netwok en Español, Vol. 20, no. 4. Available on the Internet at: http://www.fhi.org/sp/RH/Pubs/Network/v20_4/NWvol20-4HIVposwomen.htm

Girvin, Sally. 2004. Postabortion Care for Adolescents: Results from Research in the Dominican Republic and Malawi. New York: EngenderHealth

Gómez, Elizabeth. 2005. "Encuestas de Seroprevalencia de la Infección VIH Basadas en Puestos Sentinela. Resultados de Encuestas Año 2004. [Survey of Seroprevalence of the HIV Infection in Sentinel Posts: Results of the 2004 Surveys]." DIGECITSS, SESPAS

Gómez, (pediatrician at the Altagracia Maternity). 2005. Personal communication. September 14.

IPAS. La atención post-aborto [Postabortion care]. Available on the Internet at: http://www.ipas.org/spanish/womens_health/postabortion_care/default.asp

IPAS. Políticas de Salud Internacionales [International Health Policies]. Available on the Internet at: http://www.ipas.org/spanish/womens_rights_and_policies/international_health/default.asp

Ley No. 8-95 que declara como prioridad nacional la Promoción y Fomento de la Lactancia Materna [Law decalring breastfeeding promotion as a national priority]. Gaceta Oficial No. 9923.

Ley 55-93 sobre el SIDA [AIDS law].SESPAS, DIGECITS, USAID/Proyecto CONECTA. Dominican Republoic.

Lori Ashford. 2003. Necesidad insatisfecha de planificación familiar: enfoques recientes e implicaciones programáticas [Unmet family planning needs: Recent topics and programmatic implications]. In Boletín Normativo (electronic version). Population Reference Bureau/MEASURE Communication. June.

Marco Conceptual de la IPPF: Derechos del Cliente y necesidades del prestador de servicios. Cajas, en "Mejorías en la calidad [Improving quality]," Population Report, Serie J, No. 47._Available on the Internet at: www.infoforhealth.org/pr/prs/sj47/j47boxes.shtml

Miller, SueEllen; Argelia Tejada, Patricio Murgueytio et al. 2002. Strategic Assessment of Reproductive Health in the Dominican Republic, Population Council, February 15, 2002

Miric, Marija. 2006. Situation Analysis on the use of family planning in postpartum, postabortion, and PMTCT programs in the Dominican Republic: Qualitative Study]. Synergy Consulting for CESDEM, Population Council. 
Molina, Maritzae et al. Encuesta Demográfica y de Salud [Demographic and Health Survey (ENDESA2002). CESDEM, SESPAS, CERSS, COPRESIDA, USAID y ORC Macro, October 2003

Morales, Luis (Advisor in Decentralization, RedSalud). Personal communication, September 2005 Oficina Nacional de Estadística de la República Dominicana. 2002.Censo Nacional de Población y Vivienda [National Population and Housing Census]. Santo Domingo, Dominican Republic.

OPS-Macro.1996. "Dominican Republic. Demographic and Health Survey."

OPS-Macro. 2002. "Dominican Republic. Demographic and Health Survey."

Organización Mundial de la Salud (OMS [WHO]). Informe sobre la Salud en el Mundo [World Health Report]. Available on the Internet at: http://www.who.int/whr/2005/chapter3/es/index3.html

OMS, División de Salud Reproductiva. 1999. Planificación familiar postaborto: guía práctica para administradores de programas [Postabortion Family Planning: Practical Guide for Program Administrators]. Geneva, OMS [WHO].

OMS. 1996. Mejorando el acceso y la calidad de atención en planificación familiar [Improving Access and Quality in Family Planning]. Geneva: OMS [WHO].

OMS. 1995. Beneficios de la planificación familiar para la salud [Health benefits of family planning]. Geneva, WHO. Available on the Internet at http://www.who.int/reproductivehealth/publications/es/health_benefits_family_planning/index.html

OMS. 2002a. Scaling Up Antiretroviral Therapy in Resource-limited Settings. Guidelines for a Public Health Approach. Geneva: OMS [WHO].

OMS.2002b. Prevention of HIV in Infants and Young Children: Review of Evidence and WHO's Activities.Geneva: OMS [WHO]

Quiterio, Gisela and Elizabeth Ferreras. 1993. Mujeres Latinoamericanas en Cifras: República Dominicana [Data on Latin American Women: Dominican Republic]. Ministerio de Asuntos Sociales de España, FLACSO y UNICEF República Dominicana. Printed in Santiago de Chile.

RAND. 1998. "The unmet need for contraception in developing countries, Population Matters Policy Brief. Available on the Internet at: http://www.rand.org/pubs/research briefs/RB5024/index1.html

Reproductive Health Oulook. 2007. Información general: satisfacer las necesidades particulares de las diferentes etapas de la vida [General information: Satisfying the particular needs in different life stages]. PATH. Available on the Internet at: www.rhoespanol.org

Reproductive Health Outlook. 2007a. Maternidad Sin Riesgo: Aspectos claves. PATH, 2007. Available on the Internet at: www.rhoespanol.org

Rivera, Cándido. 2005. Personal conversation. September 6, 2005.

Rogo, Khana, Valentino Lema,Bertha French, and Charlotte Hort. 1998. "Establecimiento de estándares de calidad para la atención post-aborto [Establishment of quality standards for postabortion care]", Electronic journal. IPAS, Vol. 2, No. 2, November, 1998. 
Ross, John A. and William L. Winfrey. 2001. "Contraceptive use, intention to use and unmet need during the extended postpartum period," International Family Planning Perspectives. Vol. 27, No. 1, March.

Rutenberg, Naomi and Carolyn Baek. 2004. Review of Field Experiences: Integration of Family Planning and PMTCT Services. Population Council.

Sánchez, Clavel. 2005. Personal communication, September 6.

Secretaría de Estado de Salud Pública y Asistencia Social. (SESPAS) 1999. Norma Nacional de Salud Reproductiva de la República Dominicana. Planificación Familiar. SESPAS.

Secretaría de Estado de Salud Pública y Asistencia Social (SESPAS). 2001. Normas de Atención a la Mujer durante el embarazo, parto, puerperio y del Recién Nacido[National Guidelines for Maternal Care]. Serie Normas Nacionales No. 5. Comisión Ejecutiva para la Reforma del Sector Salud (CERSS). Dominican Republic, 2001.

Secretaría de Estado de Salud Pública y Asistencia Social (SESPAS). 2001. Norma Nacional de Salud Reproductiva de la República Dominicana: Planificación Familiar [National Guidelines for Reproductive Health in the Dominican Republic: Family Planning]. Serie de Normas Nacionales No. 14. CERSS, SESPAS, GTZ/EPOS-Health Consultants. Dominican Republic. Third Edition.

Secretaría de Estado de Salud Pública y Asistencia Social (SESPAS). 2002. Normas Nacionales de Alimentación para Hijos e Hijas de Madres Viviendo con el VIH/SIDA [National Guidelines for Nutrition for Children of Mothers Living with HIV. Serie de Normas Nacionales No. 31. COPRESIDA, DIGECITSS, FHI/Proyecto CONECTA, USAID/IMPACT/Implementing AIDS Prevention and Care Project. Dominican Republic,.December.

Secretaría de Estado de Salud Pública y Asistencia Social (SESPAS).2002. Normas Nacionales de Atención en Salud a la Violencia Intrafamiliar contra la Mujer [National Guidelines for Care for Domestic Violence Against Women]. Serie Normas Nacionales No. 24. SESPAS y CERSS. Dominican Republic.

Secretaría de Estado de Salud Pública y Asistencia Social (SESPAS), DIGECITSS. 2002. Programa Nacional de Reducción de la Transmisión Vertical del VIH/SIDA [National Program to Reduce PMTCT]. CONADES, Santo Domingo.

Secretaría de Estado de Salud Pública y Asistencia Social (SESPAS) SESPAS. 2003. Normas Nacionales para la Consejería en ITS/VIH/SIDA [National Guidelines for STI and HIV Counseling]. Serie de Normas Nacionales No. 30. Dominican Republic.

SESPAS and Proyecto CONECTA- FHI. 2003. "Diagnóstico de Necesidades Hospitales de la SESPAS [Diagnostic of SESPAS Hospital Needs]."

Secretaría de Estado de Salud Pública y Asistencia Social (SESPAS)/DIGECITSS/ Unidad Coordinadora de Atención Integral (UCAI). 2004. Programa Nacional de Atención Integral para las personas que viven con VIH y/o SIDA [National Program for Persons Living with HIV/AIDS]. Serie de Normas Nacionales No. 33. USAID, COPRESIDA, Banco Mundial, SESPAS, DEGECITSS, FHI, OPS/OMS, Unión Europea.CERSS, SESPAS, GTZ/EPOS-Health Consultants. República Dominicana. Serie de Documentos Técnicos No. 33, June. 
Secretaría de Estado de Salud Pública y Asistencia Social (SESPAS). 2004. Normas Nacionales de Salud Reproductiva [National Guidelines for Reproductive Health]. Serie de Normas nacionales. 1er. Nivel de Atención. CERSS, UNFPA, GTZ, Programa de Reforzamiento del Sistema de Salud y OPS. Dominican Republic. First Edition, July 2004.

Secretaría de Estado de Salud Pública y Asistencia Social (SESPAS). 2004. Protocolos de Atención en Hospitales del 2do. Y 3er. Nivel. Gineco-Obstetricia [Care Protocols for $2^{\text {nd }}$ and $3^{\text {rd }}$ level Gynecoobstetric Hospitals]. CERSS, UNFPA, GTZ, Programa de Reforzamiento del Sistema de Salud and OPS. Dominican Republic. First Edition, July 2004.

Secretaría de Estado de Salud Pública y Asistencia Social (SESPAS) Dirección General de Control de Infecciones de Transmisión Sexual y SIDA [Directorate for Control of AIDS and STIs]. 2005.

SITUACION ACTUAL DEL VIH/SIDA EN REPÚBLICA DOMINICANA. Santo Domingo, Dominican Republic

Secretaría de Estado de Salud Pública y Asistencia Social (SESPAS). 2007. Normas Nacionales de Atención para la Planificación Familiar [National Guidelines for Family Planning Care]. Comisión Ejecutiva para la Reforma del Sector Salud (CERSS) y Fondo de Población de las Naciones Unidas. Dominican Republic, $2^{\text {nd }}$ Edition, 2007.

Suazo, Amaury (head of the PMTCT program). 2005. Personal communication. May.

The Caribbean Health Research Council. 2004. "Assessment of the National HIV/AIDS Program of the Dominican Republic," prepared under the project: "Strengthening the Institutional Response to HIV/AIDs/STIs in the Caribbean Project". CARICOM, April.

Trussell, James, and Ann Pebley. 1984. The potential impact of changes in fertility on infants, child and maternal mortality," Studies in Family Planning 15(6), 267-280, 1984

UNFPA. 2005. Estado de Población Mundial 2004. El Consenso de Cairo diez años después: Población, Salud Reproductiva y Acciones Mundiales para eliminar la pobreza [State of the World Population 2004. The Cairo Consensus 10 years on: Reproductive health and global action to eliminate poverty]. Available on the Internet at: http://www.unfpa.org

Vernon, Ricardo, James R. Foreit and Emma Ottolenghi. 2006. "Introducing systematic screening to reduce unmet health needs: A manager's manual, FRONTIERS manual. Washington, DC: Population Council.

YouthNet. 2004. "Baseline PAC provider data.” Family Health International.

World Health Organization. 2005. The World Health Report 2005: Make Every Mother and Child Count. Geneva, World Health Organization. (http://www.who.int/whr/2005/en/index.html)

Zlidar, V. M. et al. 2003. "Nuevos hallazgos de las encuestas: la revolución reproductiva continúa [New Survey Findings: The Reproductive Revolution Continues],” Population Reports, Serie M, No. 17. Baltimore, Johns Hopkins Bloomberg School of Public Health, INFO Project, Spring. Available on the Internet at: http://www.populationreports.org/prs/sm17/ 


\section{Appendix 1}

Factors associated with contraceptive use in the six months postpartum: Results of multivariate logistic regression

\begin{tabular}{||l|c|c|c||}
\hline Variable & $\begin{array}{l}\text { Odds- } \\
\text { ratio }\end{array}$ & $\begin{array}{c}\text { Robust } \\
\text { S.E. }\end{array}$ & p \\
\hline Received FP counseling during ANC & 1.010 & 0.185 & 0.956 \\
\hline $\begin{array}{l}\text { Received FP counseling during } \\
\text { hospital stay for delivery }\end{array}$ & 1.556 & 0.331 & 0.037 \\
\hline $\begin{array}{l}\text { Received FP counseling during post- } \\
\text { delivery visits }\end{array}$ & 2.105 & 0.491 & 0.001 \\
\hline Stopped exclusive breastfeeding & 2.224 & 0.208 & 0.000 \\
\hline Menses have not returned & 5.895 & 0.362 & 0.000 \\
\hline$<19$ years old (ref.) & & & \\
\hline 20-35 years old & 0.723 & 0.136 & 0.085 \\
\hline$>35$ years old & 0.846 & 0.504 & 0.779 \\
\hline Less than 4 years of education (ref.) & & & \\
\hline 4 to 8 years of education & 1.164 & 0.215 & 0.411 \\
\hline Secondary school & 1.222 & 0.202 & 0.225 \\
\hline Some college & 1.917 & 0.209 & 0.000 \\
\hline Married or cohabiting & 4.211 & 0.755 & 0.000 \\
\hline 1 child or less (ref.) & & & \\
\hline Has 2 children & 1.756 & 0.132 & 0.000 \\
\hline Has 3 children & 5.082 & 1.105 & 0.000 \\
\hline Has 4 or more children & 3.964 & 0.455 & 0.000 \\
\hline & & & \\
\hline n & 1380 & & \\
\hline$\chi^{2}(14)$ & 413.75 & & \\
\hline
\end{tabular}

Note: Robust estimation was used because data were clustered in health establishments Source: Exit interviews with women in the six-month postpartum period 